\title{
FASHIONING A FUTURE. PART I: SETTLEMENT, IMPROVEMENT AND CONSERVATION IN THE EUROPEAN COLONISATION OF OTAGO, $1840-60^{1}$
}

JAMES BEATTIE

The Centre for Science in Society, Victoria University of Wellington;

Research Associate, Centre for Environmental History,

The Australian National University; Senior Research Associate,

Faculty of Humanities, University of Johannesburg

\section{Abstract}

This article, split into 2 parts that will be published over 2 journal issues, examines environmental attitudes and actions amongst the first generation of settlers in Otago, New Zealand, between 1840 and 1860. Based on extensive analysis of diaries, letters, artworks and official documents, it argues for the need to recognise the complexity of European environmental responses and actions, including highlighting extensive official attempts at forest conservation from the late 1840s. Part I of this article examines the complexity of settler views by demonstrating the importance of the concept of improvement as a means by which colonists sought to Europeanise Otago through introductions of familiar plants and animals, and the establishment of farms. Part II is in 2 sections: Section 1 considers the impact of Romanticism on settler interpretations of Otago's environment, including the manner in which they framed and depicted its harbours and mountains in writing and art. Section 2 examines concerns over resource depletion and details official measures to protect forests, including through reservation, licensing of timber extraction and the appointment of forest guards.

Keywords: environmental history, colonisation, Otago, conservation, urban environmental history, forest history, garden history, acclimatisation, romanticism, history of energy

1 This article relies on research conducted in 1999, 2006 and 2019-20. I would like to thank Jenny Chen, Acting Archivist, Toitū Otago Settlers Museum (OSM), and Emma Knowles, Jill Halley and Tania Connelly, her predecessors as Archivist, for their enthusiasm and help, as well as Séan Brosnahan, Claire Orbell and Pete Read of the Toitū Otago Settlers Museum, staff of the Hocken Library and Austin Gee. The manuscript has benefited immensely from the comments of Michael Reilly, Mike Roche, Liz Sherwood, Paul Star and Jonny West as well as the 2 anonymous reviews. I also thank helpful conversations with Tom Brooking, Gerard O'Regan, Eric Pawson, Megan Potiki, Mike Stevens, Ryan Tucker Jones, Richard Walter and Graeme Wynn. 
'... the scrub was cut with axes and billhooks, dragged into heaps and burned ... the trees were felled'.

\section{McLeod C. Orbell, undated}

Europeans as agents of environmental destruction is a common theme in Aotearoa New Zealand's environmental history. ${ }^{3}$ Nineteenth- and twentieth-century European settlers firmly regarded it as their Christian duty to make 'untamed nature ... subservient to the use of men and do service to God', as the Lutheran missionary Johan Wohlers, based on Ruapuke Island, forcefully wrote. ${ }^{4}$

Yet, in the clamour for what settlers called 'improvement'-involving the introduction of plants and animals as well as farming systems and lifestyles from Europe-it is often easy for historians and geographers to overlook the complexity of settler responses to the environment, especially during the early decades of $\mathrm{New}$ Zealand's colonisation from 1840. In the opinion of the historical geographer Alan Grey, for instance, '[t]he promise of profit provided sufficient moral warrant in an atmosphere where human self-interest determined morality and the natural physical order was not seen as deserving of any necessary respect'. ${ }^{5}$

This article disputes whether, as Grey argues, New Zealand's early settlers were simply driven by self-interest, oblivious to moral considerations and disrespectful of the environment around them. It does so by examining settler environmental attitudes and actions in Otago between 1840 and 1860. Part 1 overviews environmental change and European settlement in Otago and demonstrates that by improvement settlers sought to Europeanise Otago through introductions of familiar plants and animals, as well as the establishment of farms from home. In Part II of the article, Section 1 considers the impact of Romanticism on settler interpretations of Otago's environment, including the manner in which they depicted its harbours and mountains in writing and art. Section 2 examines settler attempts to conserve resources, mainly forests. In discussing European environmental beliefs and actions,

2 McLeod C. Orbell, 'Reminiscences 1849-1870' (typescript MS 46 Copy 86 OSM), 29, 53-58.

3 On which historiographical point, see James Beattie, 'Wilderness Found, Lost and Restored: The Sublime and Picturesque in New Zealand, 1830s-2000s', in The Future of Wilderness in Aotearoa New Zealand, ed. Richard Reeve and Mick Abbott (Dunedin: Otago University Press, 2011), 91-105.

4 J. F. H. Wohlers, Memories of the Life of J. F. H. Woblers: Missionary at Ruapuke New Zealand. An autobiography translated from the German by John Houghton (Dunedin: Otago Daily Times \& Witness Newspapers, 1895), 139.

5 Alan Grey, Aotearoa and New Zealand: A historical geography (Christchurch: Canterbury University Press, 1994), 23. 
the article does not focus specifically on the Kāi Tahu / Ngāi Tahu (the Māori tribe which occupies the Te Wai Pounamu / South Island) experience of environmentthis is examined in a number of other fascinating studies. ${ }^{6}$

What inspires the present study, in particular, is Paul Star's revisionist work on European environmental actions and attitudes in Dunedin, which focused on the period after 1868. Star's study revealed a richly complex and varied set of European attitudes and actions towards indigenous nature. In particular, his findings, while revealing environmental destruction, challenged characterisations of 'nineteenthcentury Europeans in New Zealand ... as uncaring pioneers, who feared or hated the bush and who wrote off native species as biologically bound for extinction'? The second work to which this study responds is Neil Clayton's dissertation of 1998. This examined mismatches between European environmental assessment and policy, a tension that Clayton explored using early Otago land legislation. ${ }^{8}$ Clayton's work, as well as my own from 1999, touched on early forest conservation efforts. 9 In this article, I hope to reveal something of the complexity of the first generation of European settlers and, in doing so, document earlier European environmental transformation and attitudes than Star examined. I also consider in greater depth than either Clayton or my earlier work, European attempts to conserve resources.

\section{Environment, population and settlement}

The Province of Otago, in New Zealand's South Island / Te Wai Pounamu (Figure 1), is a region of much geographical variation. A maritime climate prevails on the east coast, moderating temperatures. Inland, a 'semi-arid "continental" climate' gives considerable winter-summer temperature extremes. ${ }^{10}$ Whereas plentiful rain falls in coastal Otago, Central Otago lies in the rain shadow of Te Tiritiri-o-te-moana / the Southern Alps, a mountain range running along the middle of the South Island.

\footnotetext{
6 Khyla J. Russell, 'Landscape: Perceptions of Kai Tahu I Mua, Āianei, Ā Muri Ake' (PhD diss., University of Otago, 2000); Atholl Anderson, The Welcome of Strangers: An Ethnohistory of Southern Maori AD 1650-1850 (Dunedin: Otago University Press, 1998); Jonathan West, The Face of Nature: An Environmental History of the Otago Peninsula (Dunedin: Otago University Press, 2017); Michael J. Stevens, 'Kāi Tahu me te Hopu Tìtī ki Rakiura: An Exception to “Colonial Rule”?', Journal of Pacific History 41, no. 3 (December 2006): 273-91. On disease and public health: Pamela Wood, Dirt: Filth and Decay in a New World Arcadia (Dunedin: Otago University Press, 2005).

$7 \quad$ Paul Star, 'New Zealand's Changing Natural History. Evidence from Dunedin, 1868-1875', New Zealand Journal of History 32, no. 1 (1998): 69.

8 Neil Clayton, 'Settlers, Politicians and Scientists: Environmental Anxiety in a New Zealand Colony' (Post-Graduate Diploma in Arts diss., University of Otago, 1998).

9 James Beattie, 'Lusting after a Lost Arcadia: European Environmental Perception in the Otago Area, 1840-1860' (BA Hons Diss., University of Otago, 1999).

10 G. R. Macara, The Climate and Weather of Otago, 2nd ed. (NIWA Science and Technology Series Number 67, 2015), 7.
} 


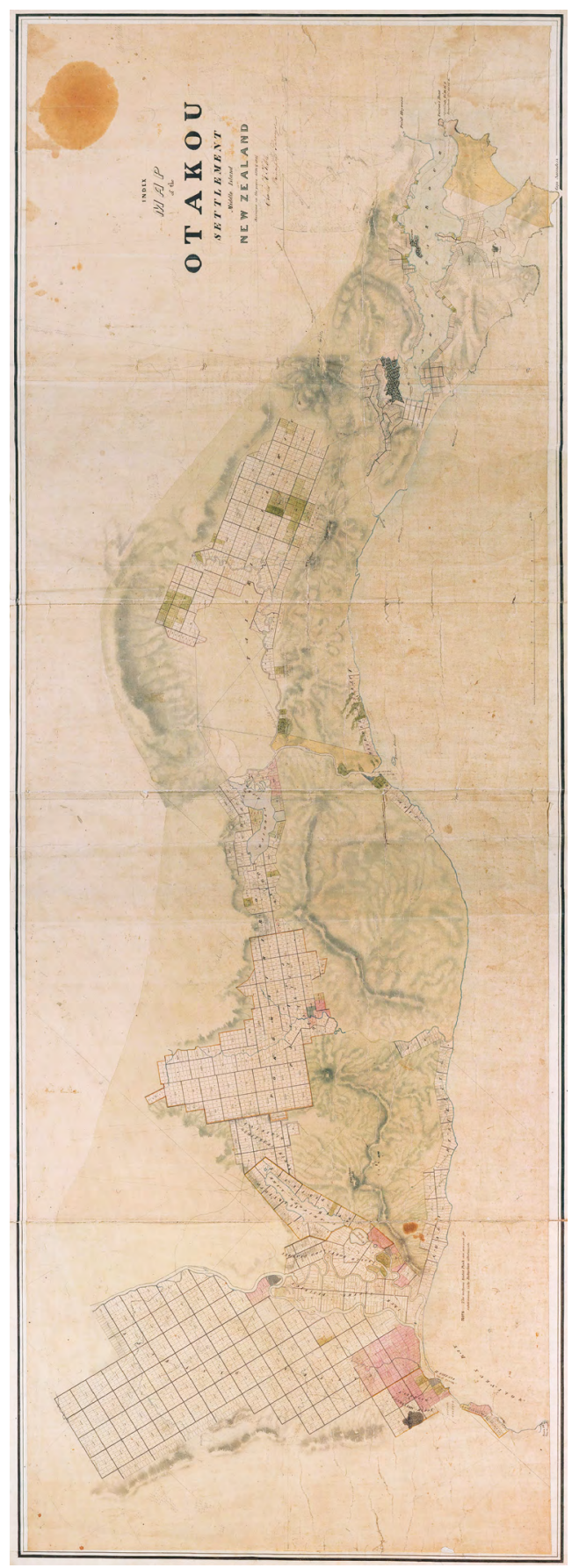

Figure 1: Index Map of the Ōtākou Settlement Middle Island New Zealand Surveyed in the years 1846 and 1847, by C. H. Kettle [189 x $65 \mathrm{~cm}$ inside border, 1 mile to 1 inch].

Source: National Archives of New Zealand, R698465. 


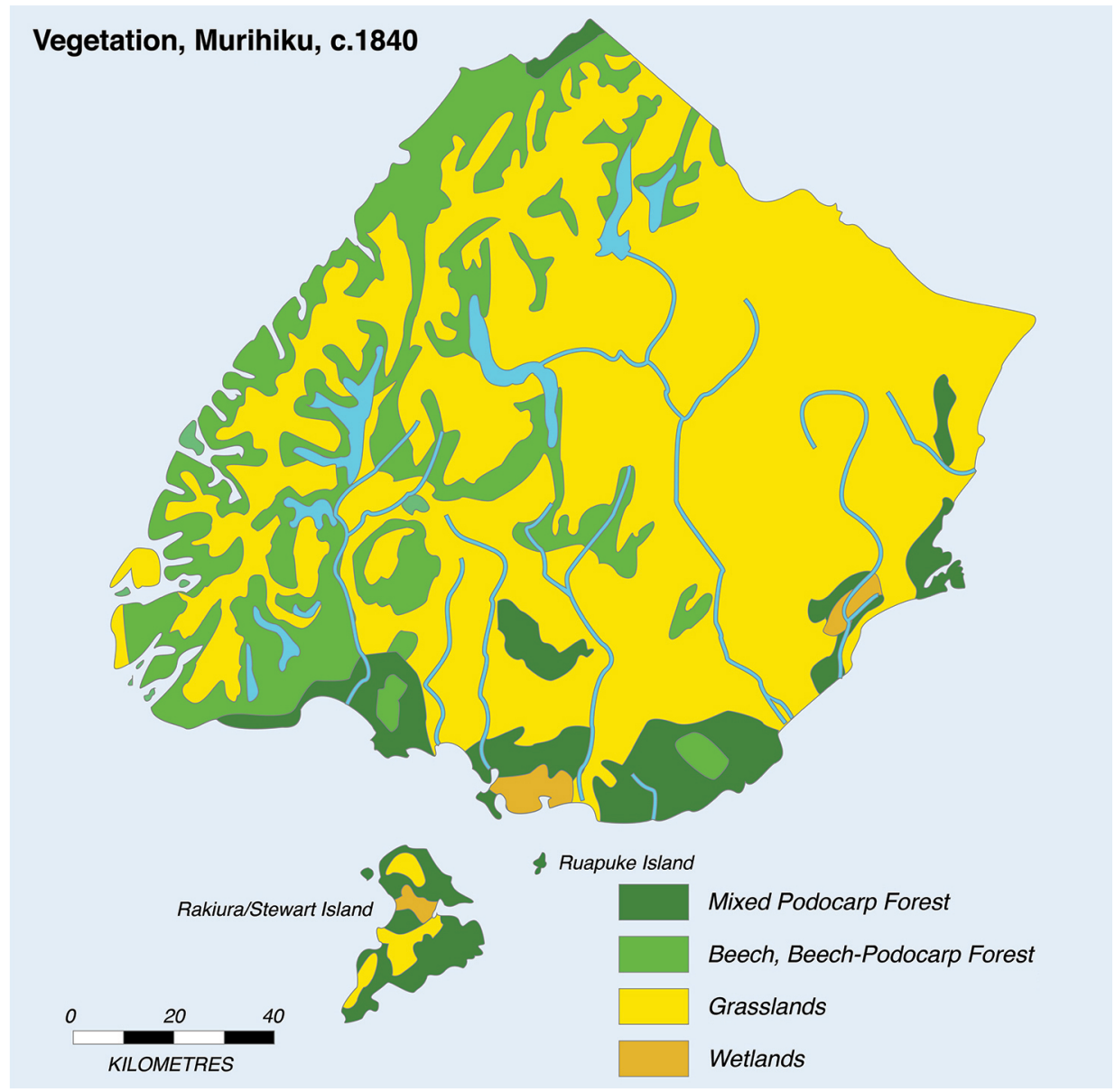

Figure 2: Forest distribution in Murihiku, c. 1840.

Source: Author's own, adapted and based on M. A. Bathgate, 'The Maori occupancy of Murihiku, 1000-1900 A.D.: A Geographic Study of Change' (MA diss., University of Otago, 1969), figure 7, 57.

The distribution of rainfall, vegetation and relief shaped the actions of 2 groups of peoples who made a home in these islands. Significantly, extensive forest clearance and its replacement with native grasses by Màori provided ideal conditions for the introduction of sheep consequent with European settlement. As the biogeographer and historical geographer Peter Holland notes, 'the widespread tussock grass, herbaceous, and low shrub communities [created by Māori burning] were a blessing as a source of palatable tissues for livestock and for shelter from the cold winds of winter and spring' (Figure 2). ${ }^{11}$

11 Peter Holland, 'Room for All? European Settlers and Native Plants in the Southern New Zealand Lowlands: 1850-1920', in Sharing Spaces: Essays in Honour of Sherry Olson, ed. Robert Sweeny et al. (Ottawa: University of Ottawa Press, 2020), 43. 

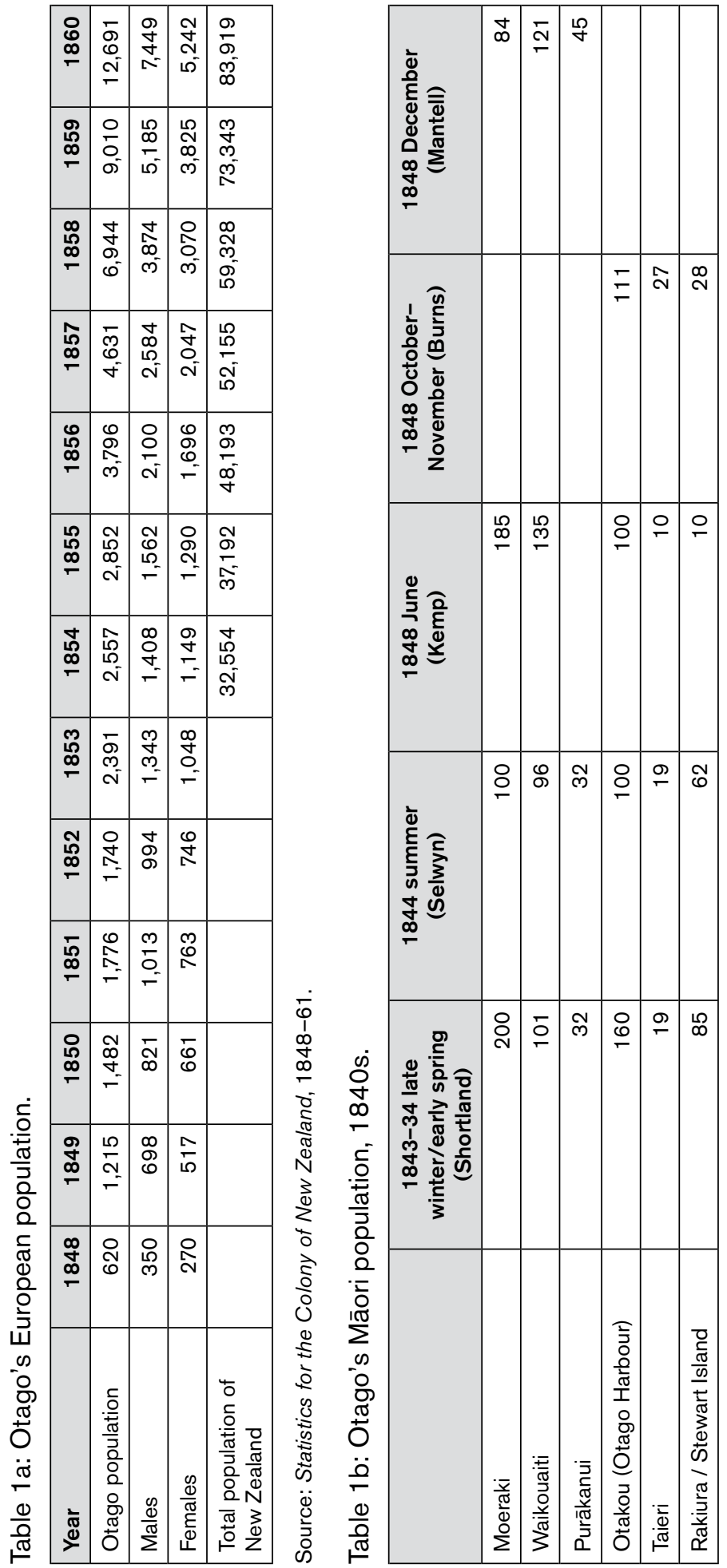

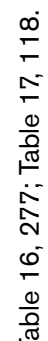

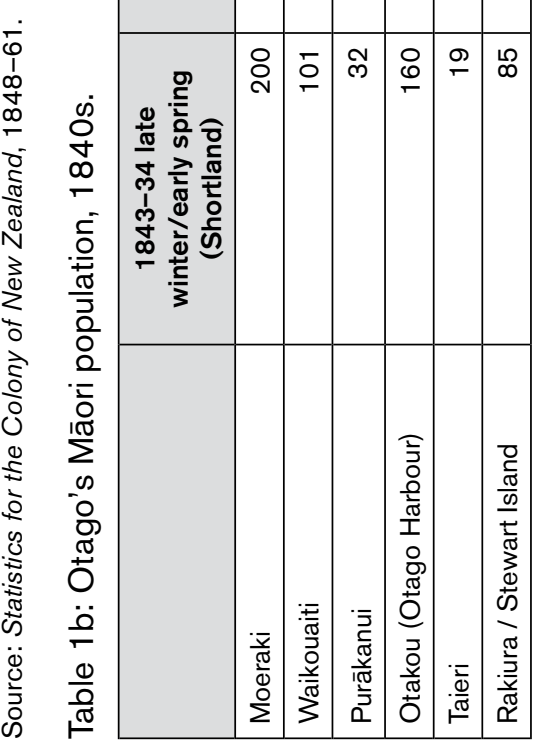

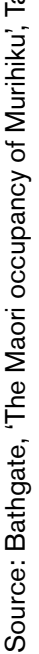


Between 1840 and 1860 a permanent European presence on Kāi Tahu land in Otago grew considerably, following full-scale planned colonisation begun in 1848 by the New Zealand Company (NZC). The Ōtākou Block, of 400,000 acres, comprising the first Käi Tahu sale to the NZC in 1844, expanded over the following 20 years to encompass almost all of Te Wai Pounamu by $1864 .{ }^{12}$ And the handful of Europeans and other groups living there as whalers by 1840 steadily grew in number to some 590 by 1850 , and over 12,000 by 1860 (Table 1a). ${ }^{13}$ Māori population and settlement in Otago also changed, in response to the effects of disease and their concentration on reserves (Tables $1 \mathrm{~b}$ and $1 \mathrm{c}$ ).

Table 1c: Otago's population, 1858.

\begin{tabular}{|l|r|r|r|}
\hline Place & Male & Female & Total \\
\hline New River \& Oue & 18 & 14 & 32 \\
\hline Jacob's River & 40 & 36 & 76 \\
\hline Orakau & 32 & 37 & 69 \\
\hline Moeraki & 69 & 47 & 116 \\
\hline Waikouaiti & 64 & 44 & 108 \\
\hline Otakou & 46 & 41 & 87 \\
\hline Taieri & 14 & 17 & 31 \\
\hline Other & 2 & 4 & 6 \\
\hline Stewart / Rakiura \& Ruapuke islands & 110 & 90 & 200 \\
\hline Otago & 395 & 330 & 725 \\
\hline
\end{tabular}

Source: F. D. Fenton, Observations on the State of the Aboriginal Population of New Zealand (Auckland: New Zealand Government, 1859), www3.stats.govt.nz/historic_publications/fenton-observationsaboriginal-inhabitants-nz/fenton-observations-aboriginal-inhabitants-nz.html?_ga=2.38613157.76790 1607.1583957493-1608443533.1562128287, accessed 12 March 2019).

\section{Environmental change and the improving ideals of the Otago Settlement}

The Otago Settlement scheme of 1844-48 had a distinctly Scottish, Free Kirk flavour. As Tom Brooking writes, its founders, the Revd Thomas Burns (17961871) and William Cargill (1784-1860), shared a mutual loathing of urbanism and industrialisation and sought to keep Otago and its principal settlement Dunedin a concentrated community of family-orientated, small-farming Presbyterians of

12 Harry C. Evison, The Long Dispute: Maori land rights and European colonisation in southern New Zealand (Christchurch: Canterbury University Press, 1997).

13 Peter Entwisle, Behold the Moon: The European Occupation of the Dunedin District, 1770-1848 (Dunedin: Port Daniel Press, 1998), 79-106. There were 307 males and 283 females in Dunedin in 1850: Otago Journal 8 (March 1850): 111. 
the Free Church. ${ }^{14}$ The settlement attempted to follow the precepts of the NZC, founded by the visionary Edward Gibbon Wakefield (1796-1862). Wakefield sought to create conditions for ordered and civilised colonisation by maintaining concentrated settlement through controlling the price and availability of land as well as ensuring a gender balance of migrants. ${ }^{15}$ Reality scuppered Wakefield's dreams and the intentions of Cargill and Burns. First, both the NZC and the Otago settlement struggled financially, the former relinquishing its charter in 1850. Nor did the ideals of closer settlement prevail, since Otago came to rely on the income produced by pastoralism. Finally, the significant presence of the 'Old Enemy' - that is, the English - threatened the religious exclusivity of the settlement, which was well and truly dissolved with the discovery of gold in 1861 and the influx of Irish and other groups. ${ }^{16}$

When Europeans arrived, the paramount Kāi Tahu settlement was at Ōtākou, located near Taiaroa Head, at the entrance to Otago Harbour (Figure 3). Sizeable Māori settlements also existed northward from Dunedin, at Waikouaiti and Moeraki, in addition to smaller ones at Pūrākanui, Taieri Mouth and Maitapapa, inland on the Taieri Plains at the confluence of the Taieri and Waipori Rivers (Table 1b). Further south, significant settlements existed in the Te Ara a Kiwa / Foveaux Straits area, notably on Ruapuke Island (Table 1c). ${ }^{17}$

Although contact brought considerable opportunities to Māori, it also brought a devastating demographic collapse. Introduced diseases, such as measles and influenza, had major social, psychological and economic impacts. This only added to the major disruption to life caused by the conflict with Ngati Toa in the 1830s. As an example, introduced diseases reduced Ōtākou's population dramatically: from 160 in 1844 to 111 by 1848 , and only 80 by $1861 .{ }^{18}$ Käi Tahu leader Hone Tūhawaiki (c.1810-44) captured the devastating impacts of disease on his tribe in a speech of 1844 at Ohinetu hill, complaining of 'new plagues, unknown to our fathers', resulting in the disappearance of '[w] hole families'. ${ }^{19}$

14 Tom Brooking, 'The Great Escape: Wakefield and the Scottish Settlement of Otago', in Edward Gibbon Wakefield and the Colonial Dream: A Reconsideration (Wellington: Friends of the Turnbull Library, 1997), 127-30.

15 This of course is a simplification of Wakefield's ideas. See Patricia Burns, Fatal Success: A History of the New Zealand Company (Auckland: Heinemann Reed, 1989); the collection of essays of Edward Gibbon Wakefield and the Colonial Dream; Erik Olssen, 'Mr Wakefield and New Zealand as an Experiment in Post-Enlightenment Experimental Practice', New Zealand Journal of History 31, no. 2 (1997): 197-218.

16 Olssen, A History of Otago, 30-56.

17 Anderson, Welcome of Strangers, 186-204. See 'Census of Kaika in the Otago Block, February-March 1852', in W. B. D. Mantell, Journal and Notebook, 1851-52, Alexander Turnbull Library, MS 1528, reproduced in Peter Tremewan, Selling Otago: A French Buyer, 1840, Maori Sellers, 1844 (Dunedin: Otago Heritage Books, 1994), 90-6.

18 West, The Face of Nature, 134.

19 George Clarke, Notes on Early Life in New Zealand (Hobart: Walch, 1903), 62-3, cited in Tremewan, Selling Otago, 38. 


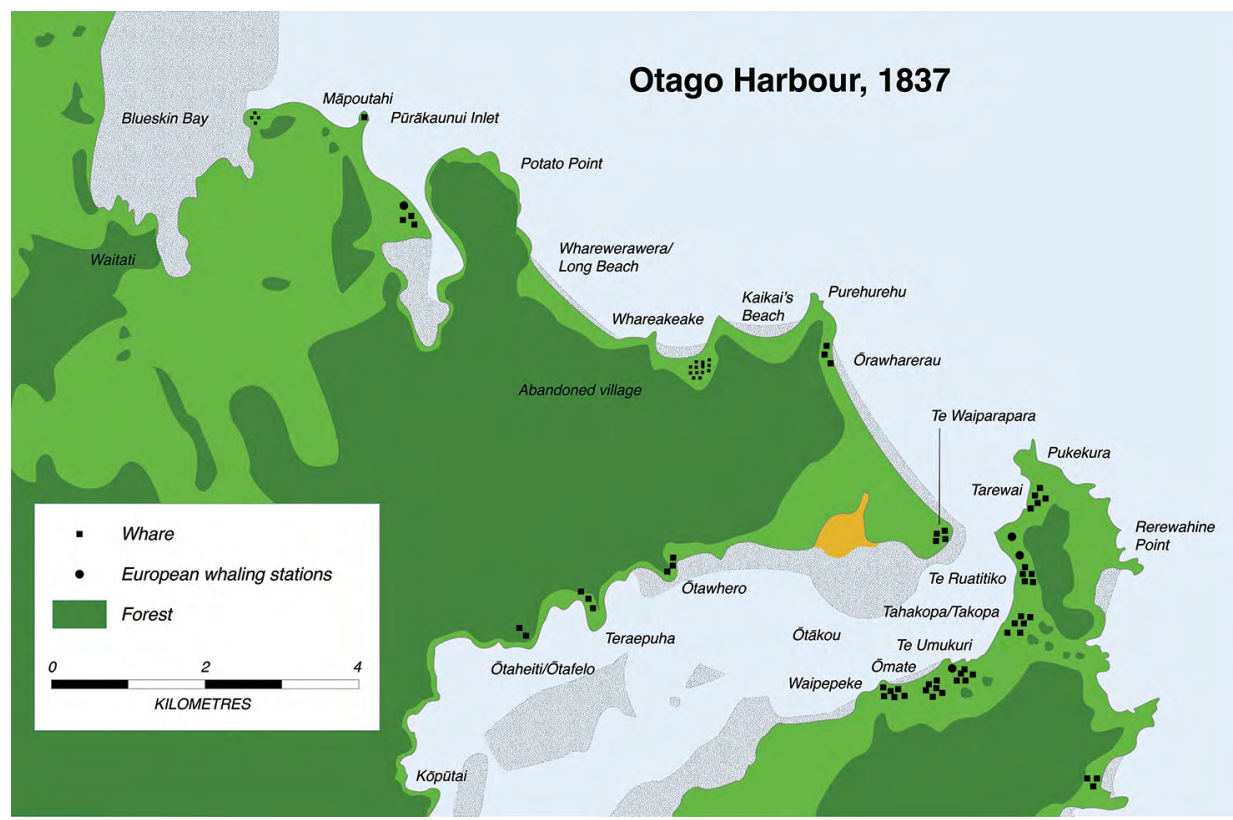

Figure 3: Māori settlements near Ōtakau, c. 1837.

Source: Adapted and based on information from Bathgate, 'The Maori occupancy of Murihiku, figure 22; Atholl Anderson, The Welcome of Strangers: An Ethnohistory of Southern Maori A.D. 1650-1850 (Dunedin: Otago University Press, 1998), Peter Entwisle, Behold the Moon: The European Occupation of the Dunedin District, 1770-1848 (Dunedin: Port Daniel Press, 1998), Khyla J. Russell, 'Landscape: Perceptions of Kai Tahu I Mua, Āianei, Ā Muri Ake' (PhD diss., University of Otago, 2000); Peter Tremewan, Selling Otago: A French Buyer, 1840, Maori Sellers, 1844 (Dunedin: Otago Heritage Books, 1994); and conversations with Matthew Campbell, Megan Potiki, Gerard O'Regan, Richard Walter.

In undertaking the arduous and dangerous journey to the other end of the world, regardless of their creed, Otago's settlers sought out their 'Promised Land'. In it, as Brooking has written, they hoped to re-establish 'the organic links between nature and community, and individual and community, which had been destroyed by unfettered capitalism'. ${ }^{20}$ By nature and community, they resolutely meant Europeanstyle land use and settlement, rather than the unique southern Māori culture that had developed, based around shifting use of the resources of land and sea. Settlers instead aimed to plant a godly, pre-industrial European society in what they regarded as the rich and under-utilised soils of southern New Zealand.

Colonists introduced plants and animals familiar to them from Europe, even if many did not necessarily originate there. ${ }^{21}$ They established farms and towns. And they reproduced the institutions and ways of seeing and valuing resources from their homeland. Achieving the ideals of concentrated farming and pastoralism required

20 Brooking, 'The Great Escape', 131.

21 James Beattie, 'Biota Barons, "Neo-Eurasias" and Indian-New Zealand Informal Eco-Cultural Networks, 1830s-1870s', Global Environment 13 (2020), 134-165. 
bush clearance and other activities settlers regarded as landscape 'improvements', such as the drainage of wetlands and introduction of those grasses that sheep and cattle were used to feeding upon. A key motivation underpinning settlers' vision of what the new colony would became was the notion of civilisation. To settlers, the ideals of civilisation meant fenced fields, productive agriculture and neat farmhouses. Civilisation gave such agricultural 'improvers' the confidence that what they were doing was not only worthwhile but also foreordained.

Almost all settlers interpreted the Genesis creation account, in which God gave Adam dominion over nature, as giving humans the duty to understand and manage the natural world for the benefit of themselves. Yet dominion did not entail either despoiling or destroying that inheritance. ${ }^{22}$ By introducing plants and animals, agricultural techniques and land systems from Europe, most settlers believed that they were enhancing, not destroying, the New Zealand environment. The Otago Journal in 1848, for example, urged local settlers to exercise dominion over Otago. Waxing lyrical about the province's 'vast tracts which are waiting for the reception of man', the anonymous writer quoted from Genesis: 'The injunction and blessing ... is yet in progress of fulfilment,- "Be fruitful and multiply and replenish the earth and subdue it". 23

The improving ideals of the Revd Thomas Burns, religious leader of the fledgling Otago settlement from 1848 to 1871 , held sway over his flock. For Burns, God intended the colonists to make the land bring forth its bounty. In 1847, before he had even arrived in his Promised Land, Burns wandered with a 'prophetic eye' over the Otago of the future. Burns imagined:

the noble plains of Otago some generations hence to mark the future herds and flocks that cover the upland pastures far away to the ranges of the snowy mountainswhilst the lower lying valleys are waving with the yellow corn and the pursuits of rural husbandry the pretty farms, 'the busy mile' and the happy smiling cottages by the way side or nestling among the trees in some 'bosky deiyle' or sylvan dell—and all that a God fearing people — with a bold peasantry their country's pride and an aristocracy whose highest honour it is that they are the disciples of Christ. ${ }^{24}$

Most European settlers viewed New Zealand's environment as just such a Promised Land, a land that was simply awaiting the improving hand of settlers to shape and cultivate it. Jane Bannerman (1835-1923), an early Otago settler and Clementina

22 See, James Beattie and John Stenhouse, 'Empire, Environment and Religion: God and Nature in Nineteenthcentury New Zealand', Environment and History 13, no. 4 (November, 2007), 413-46.

23 Otago Journal 5 (1848): 66.

24 Revd Thomas Burns to Captain William Cargill, Portobello, 6 February 1847. MS 0076, Hocken Collections, University of Otago, Dunedin. 
(1803-78) and Thomas Burns' second daughter, felt that God had brought Scottish Presbyterians 'into a good land' of plenty. ${ }^{25}$ She quoted verses from Deuteronomy (8: 7-12) to describe her new home. ${ }^{26}$

The landscape the colonists wished to fashion in Otago resembled the environment they knew from home. In Lowlands Scotland 'ordered fields and spaced-out farms' complemented the great houses, which 'projected the civilizing ideals of the classical world'. In urban areas, villages and the smaller towns of the area lay 'placidly and usefully where the roads and the hedges that defined them met'. ${ }^{27}$ Bannerman nostalgically recalled the 'neat little cottages, each with a garden at the back, quiet and peaceful' of Kirkcaldy, Fife, the small Scottish town in which she grew up. ${ }^{28}$

Images of tranquillity, however, were deceptive. The improving ideals of the Enlightenment were writ large across much of Scotland's physical and social landscape at the time of Bannerman's childhood; indeed, these same improving ideals would force her and many others to seek out a new home in Britain's far-flung colonies. Late eighteenth-century improving Scots landowners were experimenting with new systems of organising rural labour, new systems of tenancy and the newly refined practices of scientific agriculture. Improved crop species and crop rotation intensified agriculture, as did the privatisation of commons, but left many not only landless but also without work. ${ }^{29}$

\section{Acclimatising improvers}

In a sad and ironic twist, the settlers who came to Otago to escape the landlessness and lack of opportunities of their homeland resulting from improvement imposed on Aotearoa the very same improving ideals with the very same results on Māori that they themselves had experienced..$^{30}$ Acclimatisation of familiar plants and animals was the key means by which settles recreated their home environment in Otago. The replacement of native grasses for Europeans was widely welcomed. Wohlers introduced at the beginning of this article, reckoned that ' $\mathrm{t}$ ] he wildgrowing' native grasses were 'too coarse for sheep to thrive on'. They needed to be 'burnt away, and the soil sown with good European grasses and clover'. ${ }^{31}$ As Tom Brooking and Eric Pawson have shown, this is precisely what settlers did over the

25 Jane Bannerman, 'Reminiscences of her life to 1855 ', 48. Typescript in J. C. Wilson family papers. MS-0536-2, Hocken.

26 Bannerman, 'Reminiscences', 48.

27 Sydney Checkland and Olive Checkland, Industry and Ethos: Scotland, 1832-1914 (London: Arnold, 1984), 56-7.

28 Bannerman, 'Reminiscences'.

29 Checkland and Checkland, Industry and Ethos, 57-60.

30 Tom Brooking, Lands for the People? The Highland Clearances and the Colonisation of New Zealand: A biography of John McKenzie (Dunedin: University of Otago Press, 1996).

31 Wohlers, Memories, 200. 
nineteenth and twentieth centuries through the near-wholesale replacement of native grasses and forest with introduced grasslands. ${ }^{32}$ This increased stocking rates and set up New Zealand, for a time, to become one of the wealthiest countries in the world. Colonial statistics show the gradual expansion of cultivation in Otago, including the sowing of introduced pasture grasses (Table 2).

Table 2: Acreage and yield of European-produced crops, 1848-61.

\begin{tabular}{|l|r|r|r|r|r|r|r|r|r|}
\hline Year & Wheat & Barley & Oats & Maize & Potatoes & $\begin{array}{c}\text { Sown } \\
\text { grass }\end{array}$ & $\begin{array}{c}\text { Garden or } \\
\text { orchard }\end{array}$ & $\begin{array}{l}\text { Other } \\
\text { crops }\end{array}$ & Total \\
\hline 1848 & 0 & 2 & 2 & & 50 & & & & 54 \\
\hline 1849 & 43 & 9 & 25 & & 122 & & & & 199 \\
\hline 1850 & 136 & 13 & 44 & & 184 & & & & 377 \\
\hline 1851 & 338 & 28 & 267 & & 237 & 169 & & & 870 \\
\hline 1853 & 862 & 8 & 582 & & 222 & 569 & & & 2,243 \\
\hline 1854 & 1,077 & 9 & 728 & & 277 & 712 & & & 2,803 \\
\hline 1855 & 1,267 & 5 & 687 & & 386 & 1,314 & 37 & & 3,696 \\
\hline 1856 & 1,930 & 21 & 805 & & 355 & 1,718 & 117 & 76 & 5,022 \\
\hline 1857 & 1,872 & 83 & 1,754 & & 464 & & 132 & 32 & 4,337 \\
\hline & & Barley and oats & & & & & & \\
\hline 1858 & 1,831 & 198 & & & 476 & 3,695 & & & 6,200 \\
\hline 1859 & & & & & & & & & \\
\hline 1860 & & & & & & & & & \\
\hline 1861 & 5,065 & 187 & 4,859 & & 838 & 8,426 & 609 & 370 & 20,354 \\
\hline
\end{tabular}

Source: 1848-51: Bruce G. Hardie, Statistics of New Zealand for the Crown Colony period, 1840-1852 (Auckland: Dept. of Economics, Auckland University College, 1954; 1853-56): No 52 'Comparative Table showing (as nearly as can be ascertained) the quantity of land (in acres) under Crop, and fenced, in the Colony of New Zealand', 1853-6, Statistics of New Zealand for 1853, 1854, 1855, and 1856 (Auckland: Government Printer, 1858). Data unavailable for 1859 and 1860.

The importance of introducing new plants is apparent right from almost the very first activities of the NZC. Charles Henry Kettle (c. 1821-62), Chief Surveyor of Otago who oversaw the planning of Dunedin and the Otago area, established experimental plots of wheat and corn in $1846 .{ }^{33}$ In the early years of settlement especially, an established and productive garden represented the difference between life and death. Just how much so is illustrated by Otago migrants' reliance on Kāi Tahu for their food supplies in the first years of settlement. Māori supplied settlers with both fish and potatoes. ${ }^{34}$ Settlers also received supplies from John Jones' settlement of Matanaka. In this period, Māori engaged in a thriving export trade with Sydney. Putting down roots.

32 Tom Brooking and Eric Pawson, eds, Seeds of Empire: The Environmental Transformation of New Zealand (London: I. B. Tauris, 2010).

33 [Charles] Kettle to [Edward Gibbon] Wakefield, 4/46, 25 January 1847, Hocken.

34 West, Face of Nature, 179-80. On shifts in Kāi Tahu food production, see the comments by Horomona Pohio (c. 1825-81), reproduced in Tremewan, Selling Otago, 62. 
Most colonists introduced plants familiar to themselves from their home into their gardens. Jane McGlashlan's (1827-94) diary entry typifies many of the time. In 1853, she observed that '[w] have many of the old home favourites here. Roses, Pansies, Carnations, daisies, hedges of Sweet Briar and the "bonny bonny broom" 35 which is perfectly glowing just now' ${ }^{36}$ Flower growing, rather than raising vegetables or keeping stock, exemplifies best the effort given over to purely matters of the heart, rather than to the needs of the belly. The effort expended in raising flowers from home demonstrates, at least in the early years of settlement, the challenge Europeans sometimes faced in having to shift their gaze and appreciation to native species. ${ }^{37}$

In terms of garden seeds, Otago benefited from the later timing of its settlement in Australasia, which meant that settlers could obtain seeds and plants from other parts of the country and abroad. ${ }^{38}$ As early as 16 June 1849 William Cutten's store as well as A. Anderson on Princes St were offering for sale vegetable seeds, and kitchen garden and flower seeds respectively. ${ }^{39} \mathrm{~A}$ rival, James H. Stirling, also operated in Princes Street, and advertised 'well selected garden seeds' on 7 July $1849 .{ }^{40}$ The relative scarcity of plants kept prices of some varieties high for a time. Sarah Low, Burns' daughter, in 1849 wrote that 100 strawberry plants cost $£ 3 .{ }^{41}$ By the 1850s, Otago settlers could purchase a wider variety of plants locally, from several nursery firms.

In this respect, Dunedin was well served by gardeners. One of these, William Martin (1823-1905), set up business at nearby Fairfield, laying out 10 acres in garden. ${ }^{42} \mathrm{He}$ advertised a variety of fruit trees for sale in July 1850: apples, pears, cherries as well as gooseberries and other currants. ${ }^{43}$ Thereafter, Martin's business grew. Another early Dunedin nurseryman, George Matthews (1812-84), arrived in 1850 , and established a nursery at Moray Place in the central city. Later, Matthews bought property at suburban Mornington on which he developed a shrub and tree nursery, named Hawthorn Hill (now Hawthorn Avenue). ${ }^{44}$ Many, like Martin and Matthews, had been apprenticed on the larger Scottish and English estates, and so

\footnotetext{
35 Broom was later to become a curse to farmers because of its ability to spread owing to its dense root system and because it did not fix nitrogen.

36 Jane McGlashlan, 8 October 1853. Journal of Voyage 'Rajah', 14 June 1853 - 3 December 1853. Typescript MS 35, Copy 67, Toitū Otago Settlers' Museum, Dunedin.

37 I am indebted to Paul Star for this observation.

38 Louise Shaw, A History of the Dunedin Horticultural Society, 1851-2001 (Dunedin: Dunedin Horticultural Society, 2000).

39 Otago News, 7 July 1849.

40 Ibid.

41 Shaw, Dunedin Horticultural Society, 19.

42 William Martin, 'Early History of Fairfield', November 1963. Typescript in Martin DC-0320, Toitū.

43 Otago News, 20 July 1850.

44 Ruth A. Gow, 'George Matthews', in The Advance Guard Series I, ed. G. J. Griffiths (Dunedin: Otago Daily Times, 1973), 97-110.
} 
brought considerable horticultural experience (as well as seeds) with them to Otago. ${ }^{45}$ Several had also received a good education. Martin, for example, had taken courses in botany, mathematics, Hebrew, Greek and surveying at Edinburgh University. ${ }^{46}$

Martin brought many plants with him from Britain and elsewhere. By 1861 his nursery had 'a wide variety of trees, shrubs, fruit trees, pines, hedge plants, and herbaceous plants, many of the importations coming from California. ${ }^{47}$ In addition to seeds, Matthews brought to Dunedin everything from fruit and ornamental trees to flowers, mosses and cacti. ${ }^{48}$ Despite the later success of both Matthews and Martin, introducing plants from northern climes to southern ones represented a great challenge. Many plants failed to make it even half way around the globe. Erratic watering, extremes of heat and cold, and the ever-present danger of salt water served to destroy many a collection of living plants. Although chances tended to improve following the widespread adoption of the Wardian case-invented in the 1830s, and effectively a miniature glasshouse - and the reduction of voyage times with steamers, the shipment of living plants and seeds halfway around the world proved a chancy affair. ${ }^{49}$

As well as obtaining plants locally, many settlers continued to receive seeds from friends, relatives and commercial nurseries in Britain and elsewhere. In respect to access to seeds, New Zealand settlers benefited from the boom in gardening that took hold in the British Isles from the 1840s. In Britain and, by dint of emigration, its colonies, gardening, along with natural history, became a marker of respectability and civility, especially among the burgeoning middle and working classes (Figure 4). Aside from publications, a large number of commercial firms catered to demand for plants from near and far..$^{50}$ As noted above, Dunedin nurserymen relied upon British firms to send them seeds. In the 1850s the politician John Larkins Cheese Richardson (1810-78), for example, developed extensive vegetable and flower gardens on his Willowmead estate, Inch Clutha, more than $70 \mathrm{~km}$ south of Dunedin. Richardson grew an astonishing number of flowers. One entry, for 2 February 1857, lists an order of 32 varieties of flowers from Sutton's Seeds. These ranged from geraniums and cowslips to dahlias and Forget-me-nots'. ${ }^{51}$ In 1857 he paid $£ 818 \mathrm{~s} 5 \mathrm{~d}$ for considerable quantities of seeds from the UK nursery firm of Chatwood(?) and Cummins, sent through the wholesaler George W. Wheatley, London. Richardson received asparagus, peas, broccoli, cabbage, carrots, celery,

\footnotetext{
45 Shaw, Dunedin Horticultural Society.

46 'Mr William Martin, a Pioneer Horticulturist of Otago'. Manuscript notes by William Martin (his grandson), 3 February 1953. Martin DC-0320, Toitū.

47 Martin, 'Early History of Fairfield'.

48 Shaw, Dunedin Horticultural Society, 18.

49 James Beattie, “"The Empire of the Rhododendron”: Reorienting New Zealand Garden history', in Making a New Land: Environmental Histories of New Zealand, ed. Tom Brooking and Eric Pawson (Dunedin: Otago University Press, 2013), 241-57, 365-7.

50 On which, see Beattie, “The Empire of the Rhododendron”"

51 J. L. C. Richardson diary 1857-1860. AG-101, Toitū. He grew two varieties each of lettuce and cabbage. See entry for 4 October 1857 , for example.
} 
turnips, cucumber, spinach, red beet, Scotch kale, Windsor beans, Brussels sprouts, American cress, mustard, 'a collection of flower seeds', as well as '2 Bushels [of] mixed pasture grass. ${ }^{52}$

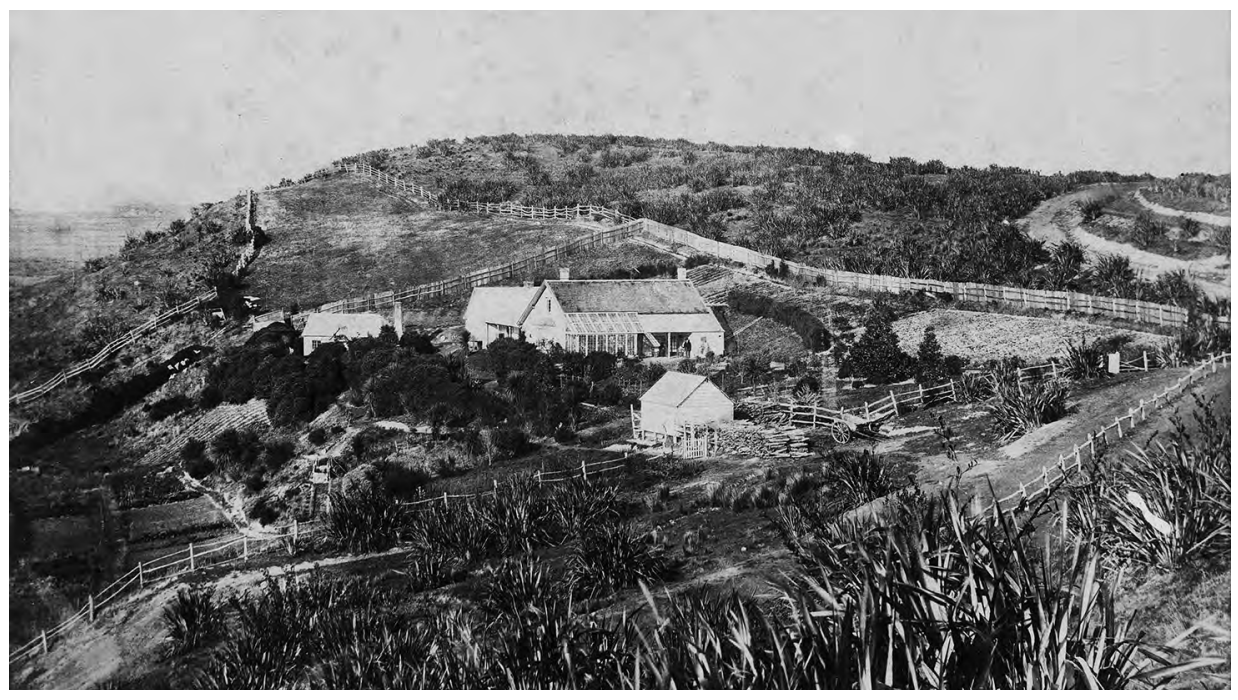

Figure 4: William Cargill was a keen plantsman, as evidenced from this photograph of his house, Hillside, in 1860, shortly before his death. Neat and well-tended, Cargill's garden contains many New Zealand native species, including Phormium tenax and Ti Kouka (Cordyline australis). Visible in the front left of the house is an extensive glasshouse.

Source: Reproduced with permission of Toitū Otago Settler's Museum. 'Photograph of "Hillside", Captain Cargill's Residence in 1860. The Captain is visible on the deck of the house', unknown photographer, 1860,179 x 245 mm, CS.13803-1, Toitū.

\section{Protecting the garden}

While settlers enthusiastically set about establishing gardens, keeping them, as well as crops, free from unwanted grazing animals was a challenge in the early years of settlement. This concern was addressed by 2 ordinances, passed by the Otago Provincial Government in the 1850s. (In addition, lease conditions also stipulated improvements to property, including fencing.) The provincial government's Fencing Ordinance, 1855, reflected environmental realities in much of Otago, in which timber was in relatively short supply. ${ }^{53}$ It replaced a New Zealand-wide ordinance. ${ }^{54}$

52 'Invoices \& Sundries, supplied by Geo. W. Wheatley of London' on the vessel Southern Cross, no date, but in 1857 Invoices. J. L. C. Richardson Invoices 1856-60. AG-101, Toitū.

53 'Fencing Ordinance, 1855', in Ordinances of the Province of Otago, N.Z., session 1 to 14 inclusive (Dunedin: Otago Witness, 1862), 47A-48A.

54 'An Ordinance to Encourage the Fencing of Land, 1847', Session 8, in Ordinances of the Province of Otago, 283. 
The Otago ordinance, as the environmental historian Michael Bagge notes, added a new section on live hedges, and legislated against the destruction of welltrimmed live hedges' and their replacement with a new wooden fence without an owner's consent. ${ }^{55}$

Settlers in relatively poorly timbered provinces, such as Otago and Canterbury, generally favoured live fences over ones constructed of timber. ${ }^{56}$ The 1855 ordinance itself represented an awareness by the Otago authorities of environmental limits, in this case of the limitations of timber supply, in their region. Although, as noted, the immediate area around Dunedin was relatively well forested at the time of first European settlement, this was generally not the case for inland and northern areas (see Section 2 in Part II of this article). ${ }^{57}$

The second measure enacted by the Otago authorities to deal with the problem of wandering stock was the Cattle Trespass Ordinance, 1858. Under its provisions, individuals whose cattle strayed within the town boundaries of Dunedin or nearby Port Chalmers could be liable for a fine of up to $£ 5$ and have their stock impounded. ${ }^{58}$ This amended several earlier ordinances dating back to 1849 . Not only did the ordinance of 1858 attempt to prevent damage to private property, but it also sought to minimise tensions within the community by providing a clear system of complaint and redress.

The problem of wandering cattle (and pigs) was not a new one. In the 1830s and 1840 s, wandering cattle from stock introduced into the Otago Peninsula settlement of Ötakou had formed wild herds. ${ }^{59}$ But their effects magnified with more intensive settlement, increased agricultural activities, and greater numbers of stock. In late 1854 Captain Edmund Bellairs (1823-96) of Pelichet Bay (now Logan Park) sent 'at the earnest request of many other aggrieved persons in this district' a letter to the Superintendent of Otago complaining of the impact of wandering stock on property and persons:

The Evil complained of is this: that large droves of cattle are depastured on the streets of the Town - that they thereby cut up the pathways made at the expense of the Public, break down fencing and drainage bridges, fill up dykes and drains, and, stopping the flow of water along the last, soon render the roadway a perfect quagmire. Added to this the bulls are, naturally, a terror to women.

55 Michael L. S. Bagge, 'Valuable ally or invading army? The ambivalence of gorse in New Zealand, 1835-1900', ENNZ: Environment and Nature in New Zealand 9, no. 1 (February 2014): 135.

56 Ray Hargreaves, 'Farm Fences in Pioneer New Zealand', New Zealand Geographer 21, no. 2 (1965): 150. Although live fencing of this kind generally found favour in provinces like Otago and Canterbury with relatively scarce timber sources, some North Island settlers showed a preference for this method of fencing, such as hawthorn in the Waikato and native Manuka fencing in Katikati in the Bay of Plenty. Ibid., 149.

57 See Neil Clayton, 'Settlers, politicians and scientists: Environmental anxiety in a New Zealand colony', ENNZ: Environment and Nature in New Zealand 9, no. 4 (2014): 26.

58 'Cattle Trespass Ordinance 1858', in Ordinances of the Province of Otago, 103-4.

59 West, Face of Nature, 146. 
That very morning, complained Bellairs, he had 'had to drive twenty[-] three head of Cattle from the street leading to the east of the Town; Two of them huge Bulls in no playful mood'. Bellairs felt 'that nothing will be done to remedy the lawless state of affairs I have been describing until some member of the Otago Executive feels the horns of a ferocious bull in some part of his proper person, which I hope will be a soft one'. ${ }^{60}$

Of the surviving records from Dunedin, which date only from 1857, it would appear that cattle trespass remained a problem throughout that decade, despite a clear desire by authorities to enforce the ordinance. From the beginning of 1857 to March 1860, the magistrate made 166 convictions, garnering fines totalling more than $£ 85$. Convictions jumped markedly in the period January $1859-$ March 1860 , rising to 125 . Previously they had been 21 (1857-58) or 20 (1858-59). ${ }^{61}$ This indicates a growing problem with wandering cattle, coincident with a higher number of settlers and stock (Table 3), in conjunction possibly with a magistrate more willing to prosecute settlers.

In 1840s Ōtākou there was only a handful of cattle, sheep and horses, in addition to many pigs. Protector of Aborigines for the Eastern Districts Edward Shortland (1812-93) enumerated 50 sheep and 12 cattle on the farm run by Octavius Harwood at the whaling station there. ${ }^{62}$ This was in contrast to the vast numbers of pigs roaming wild. At Ōtepoti-the future site of Dunedin-in the 1840s Shortland met Māori 'who had just come up the harbour to look after their pigs, of which great numbers were running at large in the bush' ${ }^{63}$ Numbers of cattle and sheep increased markedly with the 1848 Otago settlement (Table 3). This reflected the dawning reality that in Otago, although ostensibly founded as a concentrated community of small farming Presbyterians, pastoralism would rapidly become the mainstay of its economy, much to Cargill's chagrin. ${ }^{64}$

60 E. Bellairs to Superintendent, requesting police to come and stop the nuisance of stray cattle, 11 December 1854. AAAC/D500/707/Box 126, record163, item b, Archives New Zealand, Dunedin branch.

61 'Return of the number of Convictions, and the Amount of Fines received[,] at the Resident Magistrate's Court, Dunedin, for the last 3 years ending March 1860 under the Cattle Trespass Ordinance', Papers and ReturnsReturn of convictions and fines for cattle trespass to the year ending March 1860 - 20 April 1860. AAACD500701 Box 6, 79g, Archives New Zealand, Dunedin branch.

62 West, Face of Nature, 146.

63 Edward Shortland, The southern districts of New Zealand: A journal, with passing notices of the customs of the Aborigines (London: Longman, Brown, Green \& Longmans, 1851), 174-5.

64 Cargill chafed under the arrangement whereby W. B. D. Mantell as Commissioner of Crown Lands was able to dispose of land in the area outside of the Otakou Block. See Tom Brooking, And Captain of their Souls: An interpretative essay on the life and times of Captain William Cargill (Dunedin: Otago Heritage Books, 1994), 71-100; Clayton, 'Settlers, Politicians and Scientists' (1998) for perhaps the fullest treatment, see A. H. McLintock, The History of Otago: The Origins and Growth of a Wakefield Class Settlement (Dunedin: Otago Centennial Historical Publications, 1949), 239-97. 


\begin{tabular}{|c|c|c|c|c|c|c|c|c|c|c|c|c|}
\hline \multirow{3}{*}{ 음 } & $\begin{array}{c}\bar{\Phi} \\
\varpi \\
\varpi\end{array}$ & 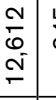 & 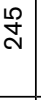 & \begin{tabular}{l}
$\stackrel{0}{0}$ \\
6 \\
- \\
\hdashline
\end{tabular} & \begin{tabular}{l}
9 \\
8 \\
0 \\
\hdashline \\
-
\end{tabular} & \begin{tabular}{|l|}
$\infty$ \\
0 \\
$o$ \\
i
\end{tabular} & 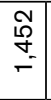 & \begin{tabular}{|c|} 
\\
0 \\
0 \\
0 \\
0 \\
0 \\
\end{tabular} & \begin{tabular}{|l}
$\infty$ \\
\\
\\
\end{tabular} & 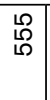 & ஓ्ల & 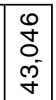 \\
\hline & 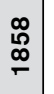 & \begin{tabular}{l|l}
$\bar{\sigma}$ & \\
+ & \\
$\bar{\sigma}$ & \\
\end{tabular} & $\begin{array}{l}\bar{g} \\
\text { s. } \\
\end{array}$ & 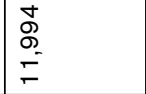 & 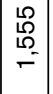 & 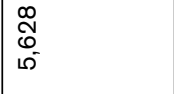 & $\vdots$ & \begin{tabular}{|l|}
0 \\
$\infty$ \\
0 \\
$\oplus$ \\
0
\end{tabular} & $\stackrel{\text { fo }}{\stackrel{O}{*}}$ & $\vdots$ & พ & 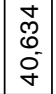 \\
\hline & 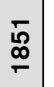 & \begin{tabular}{l|l}
8 \\
6 \\
6 \\
$5^{-}$
\end{tabular} & $\begin{array}{l}\stackrel{0}{0} \\
\stackrel{0}{=} \\
=\end{array}$ & $\frac{\infty}{m}$ & $\vdots$ & \begin{tabular}{|l|} 
\\
0 \\
0 \\
0 \\
i
\end{tabular} & 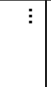 & $\begin{array}{l}\stackrel{\llcorner}{\stackrel{L}{2}} \\
\stackrel{2}{=}\end{array}$ & $\mid \begin{array}{l}\bar{\alpha} \\
\hat{m} \\
\mathcal{N}\end{array}$ & $\vdots$ & $\vdots$ & 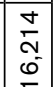 \\
\hline \multirow{3}{*}{ 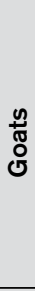 } & $\begin{array}{l}\bar{\phi} \\
\stackrel{\infty}{\leftarrow}\end{array}$ & 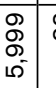 & ल्ল & $\begin{array}{l}0 \\
\stackrel{0}{\infty} \\
\stackrel{\infty}{\infty} \\
\text { i }\end{array}$ & 志 & $\frac{9}{\gamma}$ & $\begin{array}{l}\stackrel{8}{\circ} \\
\stackrel{2}{0} \\
\stackrel{-}{-}\end{array}$ & \begin{tabular}{|l|}
\multirow{2}{*}{} \\
ֻै
\end{tabular} & $\begin{array}{l}0 \\
\stackrel{10}{10} \\
\end{array}$ & $\sigma$ & $\bar{\vdots}$ & $\begin{array}{l}\frac{a}{2} \\
\bar{c}\end{array}$ \\
\hline & 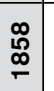 & 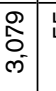 & 号 & $\begin{array}{l}0 \\
\stackrel{0}{\infty} \\
\infty \\
\text { i }\end{array}$ & $\begin{array}{l}0 \\
\infty \\
\infty \\
\infty\end{array}$ & $\begin{array}{l}\stackrel{2}{1} \\
\infty \\
\infty \\
\infty\end{array}$ & $\vdots$ & 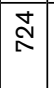 & $\frac{m}{m}$ & $\vdots$ & ஓ्ల & $\begin{array}{l}\hat{S} \\
\stackrel{2}{=} \\
=\end{array}$ \\
\hline & 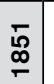 & 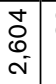 & $\begin{array}{l}\infty \\
\infty\end{array}$ & 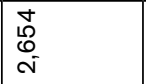 & $\vdots$ & 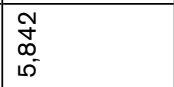 & $\vdots$ & 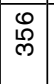 & \begin{tabular}{|c|c|} 
\\
$\infty$ \\
0 \\
10
\end{tabular} & 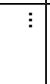 & 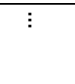 & $\begin{array}{l}\bar{N} \\
\overline{\mathbf{N}}\end{array}$ \\
\hline \multirow{3}{*}{ 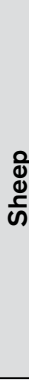 } & $\begin{array}{c}\bar{\Phi} \\
-\end{array}$ & $\begin{array}{l}0 \\
0 \\
0 \\
0 \\
- \\
0 \\
0\end{array}$ & $\begin{array}{l}0 \\
0 \\
10 \\
0 \\
0 \\
-\end{array}$ & 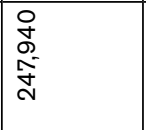 & 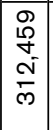 & 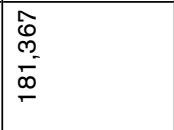 & \begin{tabular}{l|l}
0 \\
$\infty$ \\
$\infty$ \\
$\infty$ \\
$\infty$ \\
$\infty$ \\
$\infty$
\end{tabular} & 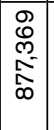 & \begin{tabular}{|l|}
0 \\
0 \\
$\infty$ \\
$\infty$ \\
0 \\
0 \\
0
\end{tabular} & $\begin{array}{l}\text { 尺 } \\
\text { o } \\
\text { న } \\
\end{array}$ & ำ & \begin{tabular}{l|} 
\\
$\infty$ \\
0 \\
0 \\
0 \\
0 \\
0 \\
\end{tabular} \\
\hline & 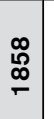 & $\begin{array}{l}\text { N } \\
\alpha \\
\infty \\
\infty \\
\infty\end{array}$ & 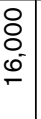 & 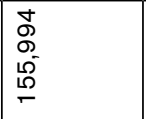 & 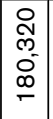 & 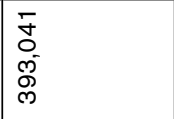 & $\vdots$ & 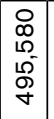 & 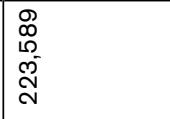 & $\vdots$ & $\infty$ & 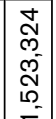 \\
\hline & $\underset{\substack{\infty \\
-}}{-}$ & $\begin{array}{l}\stackrel{0}{2} \\
0 \\
- \\
-\end{array}$ & $\begin{array}{l}\stackrel{8}{\mathrm{~N}} \\
\text { ㅎ }\end{array}$ & \begin{tabular}{|l|} 
\\
\\
\\
$\dot{0}$
\end{tabular} & $\vdots$ & \begin{tabular}{|l|} 
\\
\\
ò \\
$\delta$
\end{tabular} & $\vdots$ & 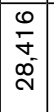 & \begin{tabular}{|l|}
$\stackrel{2}{2}$ \\
$\infty$ \\
$\tilde{e}$ \\
$\tilde{m}$
\end{tabular} & $\vdots$ & $\vdots$ & 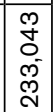 \\
\hline \multirow{3}{*}{$\begin{array}{l}\text { 㟒 } \\
\text { 苋 }\end{array}$} & $\begin{array}{c}\bar{ळ} \\
-\end{array}$ & $\begin{array}{c}\tilde{0} \\
0 \\
+ \\
0 \\
0 \\
0\end{array}$ & $\begin{array}{l}\bar{c} \\
\bar{N} \\
\bar{N}\end{array}$ & $\mid \begin{array}{l}\text { W } \\
\tilde{N} \\
o \\
o \\
q\end{array}$ & 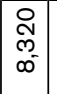 & $\begin{array}{l}\circ \\
= \\
=\end{array}$ & \begin{tabular}{|c|}
\multirow{2}{*}{} \\
$\sigma$ \\
$\infty$ \\
$\infty$
\end{tabular} & 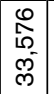 & 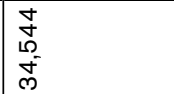 & 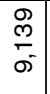 & $\bar{N}$ & 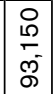 \\
\hline & 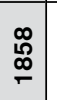 & 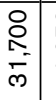 & \begin{tabular}{l} 
N \\
\multicolumn{0}{c}{} \\
\multirow{\leftarrow}{*}{}
\end{tabular} & 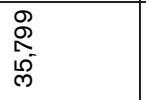 & 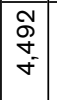 & 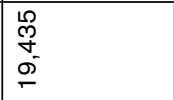 & $\vdots$ & 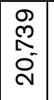 & $\begin{array}{l}\bar{\Sigma} \\
\text { 今̀ } \\
\text { ò }\end{array}$ & $\vdots$ & $\stackrel{0}{\sim}$ & 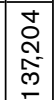 \\
\hline & $\begin{array}{c}\bar{\Gamma} \\
\stackrel{\infty}{-} \\
-\end{array}$ & 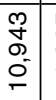 & 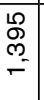 & $\begin{array}{l}\stackrel{5}{+} \\
\stackrel{+}{\leftarrow}\end{array}$ & $:$ & \begin{tabular}{|l|}
$\infty$ \\
$\infty$ \\
$\infty$ \\
$\infty$ \\
$\omega^{-}$
\end{tabular} & 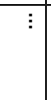 & \begin{tabular}{|l|} 
\\
0 \\
0 \\
i
\end{tabular} & $\frac{\bar{\sigma}}{\bar{m}}$ & $\vdots$ & $\vdots$ & 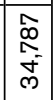 \\
\hline \multirow{3}{*}{ 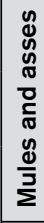 } & $\begin{array}{l}\overline{0} \\
\stackrel{\infty}{\leftarrow}\end{array}$ & $\stackrel{\text { D }}{2}$ & $\vdots$ & ร & $\sigma$ & 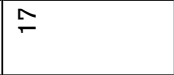 & $\simeq$ & 尺 & 10 & $\sigma$ & $\vdots$ & مِ \\
\hline & $\begin{array}{c}\infty \\
\stackrel{\infty}{0} \\
\stackrel{\infty}{-} \\
\end{array}$ & $n$ & $\mathrm{~N}$ & \& & $\infty$ & $\mp$ & $\vdots$ & 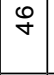 & | 10 & $\vdots$ & $\vdots$ & సิ \\
\hline & $\underset{\substack{\infty \\
\infty}}{ }$ & $\mp$ & $\vdots$ & $\stackrel{\infty}{\sim}$ & $:$ & $\stackrel{m}{1}$ & 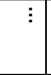 & 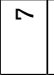 & - & $\vdots$ & $\vdots$ & 8 \\
\hline \multirow{3}{*}{ 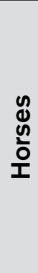 } & $\begin{array}{l}\bar{\Phi} \\
\stackrel{\infty}{-}\end{array}$ & $\begin{array}{l}\bar{\lambda} \\
0 \\
\sigma^{-}\end{array}$ & సి & $\stackrel{\tilde{E}}{\tilde{E}}$ & $\begin{array}{l}\mathcal{N} \\
\stackrel{D}{=} \\
=\end{array}$ & \begin{tabular}{|l}
0 \\
$\stackrel{0}{0}$ \\
m. \\
in
\end{tabular} & $\stackrel{0}{\frac{0}{0}}$ & $\mid \begin{array}{l}0 \\
0 \\
0 \\
0 \\
0\end{array}$ & \begin{tabular}{l}
$\stackrel{\bigcirc}{\circ}$ \\
$\stackrel{2}{*}$ \\
\multirow{\sigma}{*}{}
\end{tabular} & $\frac{N}{\infty}$ & $\vdots$ & 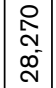 \\
\hline & $\begin{array}{c}\stackrel{\infty}{\infty} \\
\stackrel{0}{\infty} \\
-\end{array}$ & $\begin{array}{l}0 \\
\mathbb{W} \\
\infty \\
m^{-}\end{array}$ & 贴 & $\frac{\stackrel{D}{\circ}}{\text { ले }^{-}}$ & ลิ & 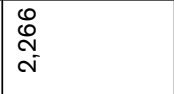 & $\vdots$ & 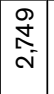 & \begin{tabular}{|l|}
0 \\
0 \\
0 \\
6 \\
-
\end{tabular} & $\vdots$ & $\vdots$ & $\begin{array}{l}N \\
\tilde{\sigma} \\
\dot{⿰} \\
\sim\end{array}$ \\
\hline & $\begin{array}{c}\bar{\Gamma} \\
\stackrel{\infty}{\leftarrow} \\
\end{array}$ & $\begin{array}{l}\stackrel{0}{0} \\
0 \\
0 \\
=\end{array}$ & $\begin{array}{l}\infty \\
0 \\
0\end{array}$ & $\begin{array}{l}\infty \\
\stackrel{\infty}{\infty}\end{array}$ & $\vdots$ & 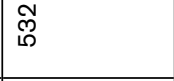 & $\vdots$ & 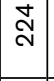 & 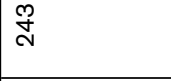 & $\vdots$ & $\vdots$ & $\begin{array}{l}\bigcirc \\
\infty \\
\infty \\
i \\
\end{array}$ \\
\hline \multicolumn{2}{|c|}{ 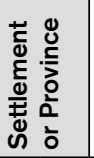 } & $\begin{array}{l}\frac{0}{2} \\
\frac{0}{0} \\
\frac{0}{0} \\
\frac{3}{2}\end{array}$ & 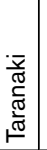 & 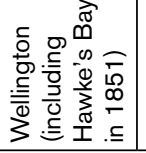 & 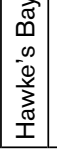 & 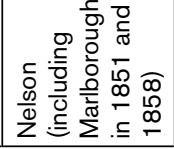 & 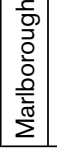 & 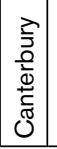 & 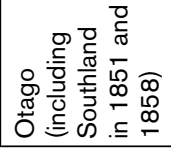 & 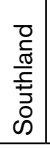 & 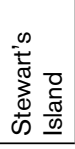 & 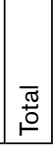 \\
\hline
\end{tabular}


Figures indicate that Māori generally kept pigs and stock. Walter Mantell (1820-95), Crown Lands Commissioner for the Southern District of New Zealand and Province of Otago (1851-55), observed in 1854 that although some Kāi Tahu expressed a preference to invest in both horses and sheep, 'the price of that description of Stock is now too high for [their] means' ${ }^{65}$ Prices of horses and sheep remained relatively high in Otago compared to other provinces (Table 4), and settlers continued to have to import livestock from other provinces or abroad.

Table 4: Livestock prices in Otago.

\begin{tabular}{|l|c|c|c|c|c|}
\hline Year & Horses & Horned Cattle & Sheep & Goats & Pigs \\
\hline 1848 & $£ 25$ & $£ 1210 \mathrm{~s}$ & $£ 1$ & $10 \mathrm{~s}$ & $£ 2$ \\
\hline 1849 & $£ 25$ & $£ 16$ & $18 \mathrm{~s}$ & $15 \mathrm{~s}$ & $£ 2$ \\
\hline 1850 & $£ 25$ & $£ 13$ & $17 \mathrm{~s}$ & $12 \mathrm{~s}$ & $£ 110 \mathrm{~s}$ \\
\hline 1851 & $£ 22$ & $£ 1010 \mathrm{~s}$ & $17 \mathrm{~s}$ & $12 \mathrm{~s}$ & $£ 2$ \\
\hline 1852 & $£ 23$ & $£ 1110 \mathrm{~s}$ & $£ 1$ & $12 \mathrm{~s} 6 \mathrm{~d}$ & $£ 115 \mathrm{~s}$ \\
\hline
\end{tabular}

Source: Hardie, Statistics of New Zealand for the Crown Colony period, table 58.

\section{Animal energy}

In keeping with this pre-industrial society, from the 1840 s to the 1860 s motive power for the settlement invariably came from energy derived from sun, wind and water. Just as the Roaring Forties propelled immigrant sailing vessels on the last leg of their often stomach-churning voyage to New Zealand, so water turbines powered mills turning timber into planks or wheat into flour. Human and animal muscle toiled to transform the land. This is the so-called biological old world in which photosynthesis lay at the basis of a series of energy transfers from plant to animal. ${ }^{66}$

As the historian Nancy Swarbrick notes, in New Zealand '[m] ost domestic animals were either stock or working animals, providing food, fibre, transport and labour of various kinds. Many were destined to be slaughtered and eaten'. ${ }^{67}$ Sheep provided mutton as well as wool. They spread over the larger runs of inland Otago-or 'Hundreds', as unsurveyed land was termed — environments already highly altered by Māori actions. Native grasslands proved palatable and useful fodder for sheep, until their gradual replacement with introduced pasture. Introduced pasture supported higher stocking numbers than native grasses. Horses—still expensive in

65 W. B. D. Mantell to Colonial Secretary, 18 March 1854, Dunedin. Outwards Letterbook Crown Lands, Southern District of New Zealand and Province of Otago, Nov. 1851 to Dec. 1855 inclusive. Walter Mantell, Commissioner of Crown Lands. DAAK/D450/9331/3, Archives New Zealand Dunedin branch.

66 On which, see J. R. McNeil, Something New Under the Sun: An Environmental History of the Twentieth Century (New York: W. W. Norton, 2000).

67 Nancy Swarbrick, Creature Comforts: New Zealanders and their Pets. An Illustrated History (Dunedin: University of Otago Press, 2013), 46. 
colonial Otago through the 1850s-reflected their value as modes of transportation, necessary for traversing the sometimes vast distances between settlements, especially in the general absence of unformed roads. They were also status symbols in both Māori and Pākehā worlds. ${ }^{68}$ In contrast, working dogs were farmers' foot soldiers, corralling sheep and keeping order amongst flocks, their role all the more important in the early years of settlement because of the relative lack of shepherds, and fences, in Otago at this time.

Hoofed animals had a major ecological impact in an environment unaccustomed to animals. Animal manure and hooves altered soil composition. Grazing impacted plant composition, structure and regeneration. ${ }^{69}$ Even on introduced pastures, cattle, while increasing nutrient cycling, also cause losses to nutrients and concentrate 'nutrients into small volumes of soil from which complete recovery by plant uptake is difficult'. ${ }^{70}$ Overstocking, moreover, can lead to soil loss and erosion. Other introduced animals, especially rabbits, were to have devastating ecological impacts on the grasslands of the inland South Island, effects that present generations are still trying to mitigate. In forests, deer, pigs and cattle strip trees and undercover, while introduced cats and dogs, as well as unwanted introductions such as rats and possums, prey on native birds. ${ }^{71}$

As early as 1854, in the area from Mataura to Aparima (Riverton), now in Southland, Mantell reported 'there is probably a far greater extent turned up by the myriads of wild pigs than cultivated by human beings and nearly as many wild cattle as tame'. ${ }^{72}$ Nor was it limited to wild cattle and pigs. In 1857 at Wairuna, near Popotunoa, South Otago, William Gordon Rich recorded the appearance of 'wild dogs' and registered his response- poison. $^{73}$

68 Carolyn Minchum, The Horse in New Zealand: Attitude and Heart (Auckland: David Bateman, 2011); Hazel Petrie, 'Satisfaction in a Horse: The Perception and Assimilation of an Exotic Animal into Maori Custom Law', in Invasive and Introduced Plants and Animals: Human Perceptions, Attitudes and Approaches to the Environment, ed. Ian D. Rotherham and Robert A. Lambert (London and Washington, DC: Earthscan, 2011), 313-26.

69 Susan M. Timmins, 'Impact of cattle on conservation land licensed for grazing in South Westland, New Zealand', New Zealand Journal of Ecology 26, no. 2 (2002): 107-20.

70 P. H. Williams and R. J. Haynes, 'Influence of Improved Pastures and Grazing Animals on Nutrient Cycling within New Zealand Soils', New Zealand Journal of Ecology 14 (1990): 54-5.

71 For the impact of these introductions, see Carolyn M. King, Invasive Predators in New Zealand: Disaster on Four Small Paws (Basingstoke: Palgrave Macmillan, 2019). Of the rabbit's impact, note Peter Holland and Guil Figgins, 'Environmental disturbance triggering infestations of gorse, rabbits, and thistles in southern New Zealand: 1850-1980', International Review of Environmental History 1 (2015): 41-79.

72 W. B. D. Mantell to Colonial Secretary, 18 March 1854. Dunedin, Outwards Letterbook Crown Lands, Southern District of New Zealand and Province of Otago, Nov. 1851 to Dec. 1855 inclusive. Walter Mantell, Commissioner of Crown Lands. DAAK/D450/9331/3, Archives New Zealand Dunedin branch.

7321 March 1857, 24 March 1857, Diary of W. G. Rich, 17 May 1852 to 31 August 1852. Typescript, Misc MS 0943b, Toitū. 
Typical of early settlers' introductions were those of Otago's patriarch, Burns. As well as introducing seeds from home, in 1847 Burns brought with him to Dunedin a 'Bull, Cow, Newfoundland' dog, as well as a cat. ${ }^{74}$ The settler Rich listed the passengers on board the vessel on which he sailed to Dunedin in 1852. As well as the Joseph Fletcher's 120 human passengers, there were:

$$
\begin{aligned}
& 300 \text { fowls } \\
& 35 \text { pigs } \\
& 12 \text { sheep } \\
& 1 \text { dog } \\
& 1 \text { cat. }{ }^{75}
\end{aligned}
$$

Some of the wealthier settlers brought considerably more stock. Many, such as Rich and Charles Suisted (1810-60), also bought stock from other provinces (usually Canterbury). ${ }^{76}$ Rich drove his newly bought sheep several hundred kilometres to his property at Wairuna, relying on their mutton for food as he progressed south. ${ }^{77}$ Otago settlers continued to import considerable numbers of stock into the 1850 s.

Cows provided valuable sources of milk and, as figures show for the 1850 s, contributed a small percentage to exports from the province in the form of butter. Turnips provided them with winter food. Fowls gave meat and eggs, food supplemented by the many pigs roaming through the bush, as well as the native birds. The large native wood pigeons (kererū, Hemiphaga novaeseelandiae) roosting on the same tree were so tame in the 1840s, observed Shortland, that he could shoot one after another. ${ }^{78}$ Near a lake or lagoon was the best place to hunt, noted McLeod Orbell, because there it 'literally teemed' with birds. ${ }^{79}$

A combination of habitat loss through deforestation and the impact of introduced predators dramatically reduced Otago's birdlife. The loss of birdsong remained a constant refrain in settler reminiscences. Jane McGlashlan initially found the bush 'enlivened by the clear notes of a beautiful yellow bird, ${ }^{80}$ and by those of the tui or parson bird (Prosthemadera novaeseelandiae) - a pretty creature, clothed in a suit of glossy green and black, with the singular tuft of white feather beneath its chin' ${ }^{81}$ McGlashlan and Sarah Low, who came to Dunedin with her husband in 1849, were

74 Thomas Burns, 28 January 1847, Diary, 27 November 1847 - 15 April 1848. Typescript, in G. C. Thomson Papers, MS 440/18, Hocken.

75 Diary of W. G. Rich, 17 May 1852 to. Typescript copy of original held in private hands, Misc MS 0943b, Hocken.

76 Julie Bremner, 'Charles E. Suisted', in The Advance Guard: series II, ed. G. J. Griffiths (Dunedin: Otago Daily Times, 1974), 99-150.

77 See diary of W. G. Rich, passim.

78 Shortland, The southern districts of New Zealand, 10-11.

79 Orbell, 'Reminiscences 1849-1870', 37.

80 Presumable Mōhua (Mohoua ochrocephala).

81 McGlashlan, 8 October 1848. 
struck by the tameness of the birds, which rapidly proved their undoing. ${ }^{82}$ Parakeets, fluttering 'about in the sunshine', and robins, 'in their sober suits of black and brown', would 'stop within a few yards of you and even perch upon your shoulder', said McGlashlan. ${ }^{83}$ Looking back to the early years of settlement, Fraser regretted her own and her fellow colonists' liking for bird meat. 'What a pity', she rued, 'it was to destroy those beautiful birds, which are now so scarce. ${ }^{\text {'84 }}$ Like Wohlers, who later lamented the introduction of that 'land plague', rabbits, Fraser wrote her comments after the event. ${ }^{85}$ Only from the 1860 s did large-scale concerns emerge over the impact of rabbits, especially in the high country. In this decade, Holland has noted that disturbance, combined with weather patterns, created conditions ideal for the spread of rabbits in these areas. The impacts-environmentally, socially and economically-were devastating. ${ }^{86}$

\section{Measuring progress}

The needs of survival gave clearing, building and enclosing especial urgency during the early years of establishing a colony. ${ }^{87}$ No doubt most settler families would have appreciated Ellen Valpy's (1827-1904) pencil drawing of Forbury Farm (Figure 5), on the edge of Dunedin, in 1857 a mere 9 years after the first migrant had arrived. ${ }^{88}$ Ploughed land, well-established homestead and outbuildings, and fenced paddocks represented what most settlers aimed to achieve in New Zealand.

Settlers measured progress by the area of land under cultivation and the amount of bush removed. Walking deep into the forest of North East Valley, Dunedin, in 1859 the settler Alexander Begg (1839-1907) observed that ' $[\mathrm{t}]$ he sound of the axe in the distance' told of 'how fast this wildness is being reclaimed'. ${ }^{99}$ The backbreaking work of bush clearance appears vividly in Orbell's reminiscences. In 1857, his family decided to build a homestead on their run near Hawksbury, some $30 \mathrm{~km}$ north of

82 Relatively little is known about the Lows other than that they were in Wellington by 1851 . They possibly left for Australia after sometime later. Tania Connelly, op. cit., 1999.

83 McGlashlan, 8 October 1848; Sarah Low, 'Larkins', 6 November 1849. Typescript, Copy 61 (original MS unknown), Toitū.

84 Anne Black Fraser, I Remember 1848-1866 (Dunedin and Wellington: no publisher, no date), 10.

85 Wohlers, Memories, 201.

86 Peter Holland, A Home in the Howling Wilderness: Settlers and the Environment in Southern New Zealand (Auckland: Auckland University Press, 2014).

87 See also William Gordon Rich, Diary of a voyage to Auckland, New Zealand from England aboard the Joseph Fletcher 17 May 1852 - 31 August 1852 and subsequent life, mainly in Otago, 26, 28 February 1855. MS 0943a, Hocken.

88 The eldest of the Valpy daughters, Ellen, married her eldest cousin, Henry Jeffreys, in 1852. The marriage, however, was not successful and Ellen fell on hard times, no doubt disappointed at her inability to earn a living through art. Jane Thomson, ed., Southern People: A Dictionary of Otago Southland Biography (Dunedin: Longacre in association with the Dunedin City Council, 1998), 526. Her sisters and mother were also gifted artists.

89 Alexander C. Begg, 16 December 1859, Diary of Voyage from Glasgow to Dunedin 8 June 1859 - 8 August 1860. Begg family papers, collected by Neil Begg. AG-497-01, Hocken. 
Dunedin. First, they cleared the bush, an activity in which everyone helped. After 'the scrub was cut with axes and billhooks, dragged into heaps and burned ... the trees were felled' and heaped up. Next, settlers fenced the area, and, finally, 'with adzes or grubbers', removed logs and the remaining stumps. For the homestead, they felled suitable timber selected from the adjoining bush, rolled it on skids to the sawing site, measured, sawed and then dragged it to the construction site. To complete the run, the Orbells established a vegetable garden and built a 50-foot-long byre. ${ }^{90}$

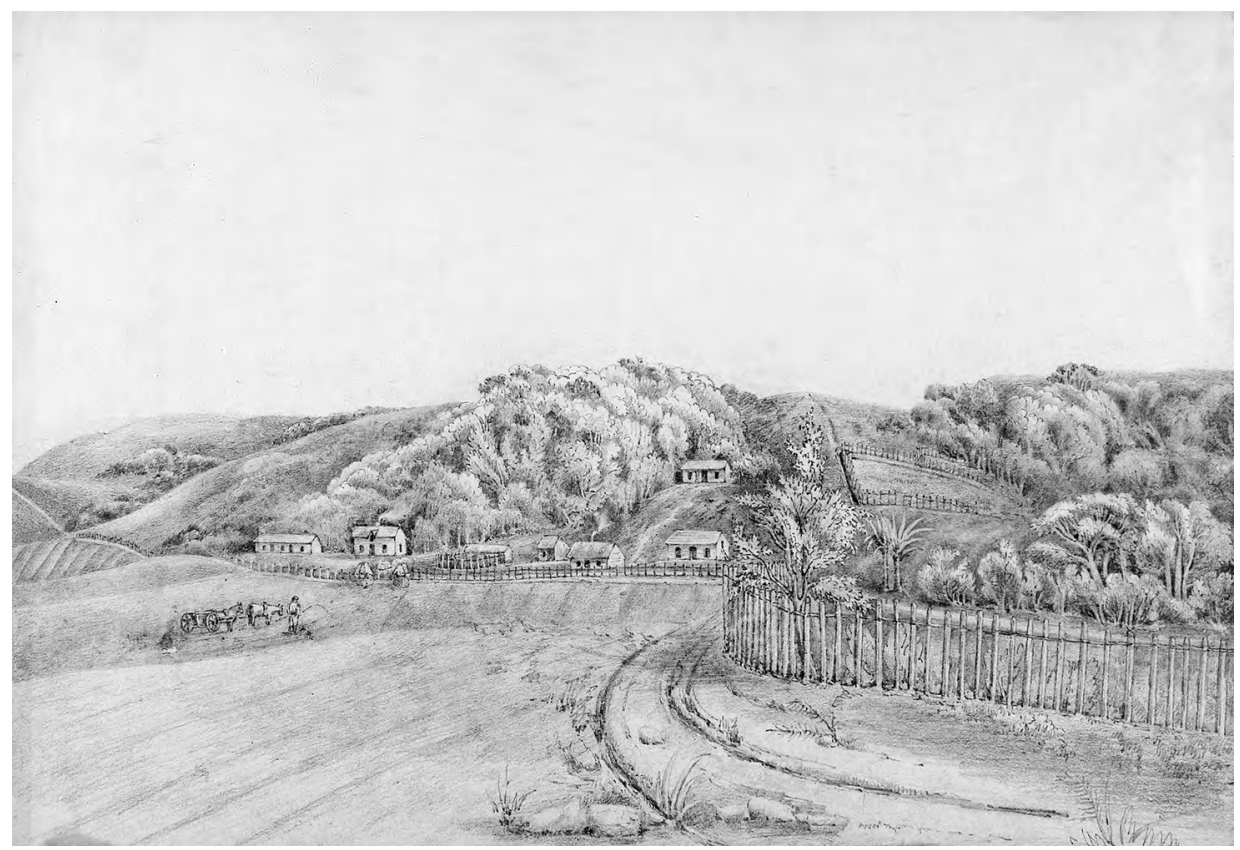

Figure 5: Ellen Penelope Valpy, Forbury Farm, circa 1857, pencil on paper, Valpy Box 3, Acc No: 1978/5684.

Source: Reproduced with permission from Toitū Otago Settlers' Museum.

Some certainly found the bush a great trial. In 1849 Low declared that Otago's trees were too tall. '[T] hen there is the undergrowth of smaller Trees and Shrubs', which, with the supplejacks (Ripogonum scandens) are so close as to render 'it impossible to walk out of the Surveyors' Paths'.$^{91}$ However, in the dozens of settler diaries, letters, reminiscences and official papers I have read, only one other colonist, an anonymous letter-writer quoted in John Cargill's published handbook for emigrants, wrote disparagingly of the bush around Otago. Unless emigrants liked the 'Sublime and beautiful', he wrote, they would be faced with only small areas of cleared forest,

90 McLeod C. Orbell, 'Reminiscences 1849-1870', 29, 53-8. Typescript, MS 46, Copy 85, Toitū.

91 Low, 6 November 1849, 1-2. 'Surveyors', punctuated. 
with temporary huts set 'amid the apparently interminable forests' ${ }^{92}$ In other words, Otago's particular landscape of forest and hills, appealing though it might be visually, was otherwise useless for agricultural pursuits.

The almost complete absence of a negative assessment of forests in Otago questions the validity of interpretations put forward by the historical geographer Paul Shepard, who claims that settlers had a generally unfavourable impression of New Zealand forests, which 'evoked gloom except when seen from the outside'. ${ }^{93}$ Perhaps the reason is that Shepard made New Zealand-wide generalisations of European environmental perception reliant on only 10 sources on the South Island. ${ }^{94}$ Another factor may have been that Dunedin was not as densely forested as the North Island. As Richardson playfully observed in 1858, Nature's 'mischievous humours' had meant that in the South Island 'where timber is required for firing and fencing, it is generally wanting, and where not required, it is to be had in abundance..$^{95}$ Richardson, a deep-thinking and far-sighted individual, also identified the need for the authorities to protect forest resources as well as to seek alternatives, such as hedging, to timber fences (see Part II, Section 2).

It would be wrong to think that settlers did not appreciate native species just because they were engaged in changing the environment. For all her pessimism, Low asked her husband to 'shoot me down pieces' of leaves from the treetops to see what they looked like. ${ }^{96}$ Bannerman 'took great pride in watching the development' of the Burns family's manse through bush clearance, yet she still appreciated native flora. Her brother, Arthur Burns, would row across Otago Harbour to collect native plants for introduction into the garden of their father's property (Grant's Braes) on Otago Peninsula. ${ }^{97}$ As this article discusses in Part II, settler environmental change did not mean that Europeans failed to appreciate existing scenery, or that they rued its passing in the name of progress.

It may in fact have been through clearance that many colonists became interested in, and aware of, native flora. In the late 1850s, Frank Mathias (1842-?), for example, 'worked at the bush all day and got down some rails \& posts [and] found a curious plant at [sic] the bush, the seeds [of which] were in the top leaves'. ${ }^{98}$ Likewise, John

92 'No. 1 - Letter from a Settler to the Colony to a Relative in Britain', Dunedin, 24 January 1860, in John Cargill, New Zealand: Information for the Guidance of Intending Emigrants (Edinburgh: Bell and Bradfute, 1860), Appendix, 33.

93 Shepard, English Reaction to the N.Z. Landscape Before 1850, Pacific Viewpoint Monograph No. 4 (Wellington: Victoria University of Wellington, Department of Geography, 1969), 3.

94 Of 105 primary references to New Zealand, only 10 (including 3 from Dunedin) refer to the South Island. Thirteen were either non-New Zealand primary or secondary sources. See ibid., 16-49.

95 Otago Witness, 10 July 1858, 6.

96 Low, 6 November 1849, 1-2. 'Surveyors' (correctly punctuated).

97 Bannerman, 'Reminiscences', 45.

98 Ibid., 45; Frank Mathias, Journal of Frank Mathias 1 October 1859 - 30 September 1861, 21. Misc-MS 1560/1, Hocken. 
McLay (1840-1916?), while working for the Burns family clearing bush, found native species 'terrible stuff' to clear, yet took great pleasure in their appearance. ${ }^{99}$ This was an experience by no means limited to Otago. In 1858 the Taranaki settler Arthur Atkinson (1833-1902) 'practised [the] Maori [language] \& [tree] felling together' while working with his Māori employee, Mohi. Indeed, Atkinson learnt much more about the natural world from Mohi, including the names of trees when felling them, and Māori practices and beliefs about deforestation and the behaviour of local birdlife. ${ }^{100}$

In assessing the natural resources of the land, surveyors and settlers alike quickly appreciated the utility of timber. Rather than serving only as an impediment to pastoralism or agriculture, the remnant bush provided raw materials for building and fencing, and a livelihood for its suppliers. As Orbell observed, 'Hawksbury Bush contained useful timber, either for sawing, fencing or shingles'. He and his brother received a contract from the entrepreneur Jones for some 200,000 shingles. Settlers, too, were aware of the scarcity of forests when selecting land. For example, in 1848, an anonymous landowner near Saddle Hill, about $18 \mathrm{~km}$ south of Dunedin, recognising the value of timber for fencing and building, made sure his property bounded a good area of forest. ${ }^{101}$ The Otago authorities protected timber to prevent its exhaustion (see Part II, Section 2).

Although highly idealised, a sense of the changes wrought in the area in and around Dunedin in the 10 years or so following initial settlement appears in 2 lithographs produced by Kettle, both designed to encourage further migration to the settlement. ${ }^{102}$ His depiction of Dunedin in 1849 (Figure 6) shows permanentlooking dwellings in neatly cleared, fenced fields. (In the middle distance in other versions of this lithograph, 2 cows stand in a field, a figure approaching them.) Figure 6 suggests progress through tree stumps in the foreground and bush retreating up the hill on the left-hand side of the picture. The message it conveys is that bush is there in sufficient quantity to provide timber, but not so much as to require large-scale clearance for migrants considering settlement in Dunedin. The inclusion of sailing ships in Otago Harbour implies regular access to the outside world and a well-established market.

99 Waikouaiti and Dunedin in 1850: Reminiscences of John McLay, an early settler, ed. Ross S. Gordon (Dunedin: The editor, 1998), 30-1, 54, 11.

100 A. S. Atkinson, 9 November 1858, in 'Diary of Arthur S. Atkinson 20 May 1853 - 5 November 1855'. MSX 3040, Alexander Turnbull Library, Wellington.

101 Clayton, 'Settlers, Politicians and Scientists' (1998), 50-6; Orbell, 'Reminiscences 1849-1870', 27, 38; 'Letter from a landowner', Otago Journal 4 (26 September 1848): 58. See also Charles Kettle, 7 April 1846, in Letterbook, 2/46.

102 High-quality copies are found at Charles Henry Kettle, 'Dunedin in 1848' [sic] (Edinburgh: A. Banks and Son), tinted lithograph, 81 x 176 mm. Au K43 94/16, Neg: 1837/13A, Hocken Library; Charles Henry Kettle, 'Dunedin in 1859' (Edinburgh: A. Banks and Son), tinted lithograph on paper, 81 x $134 \mathrm{~mm}$. Neg: 1837/12, Hocken Library. 


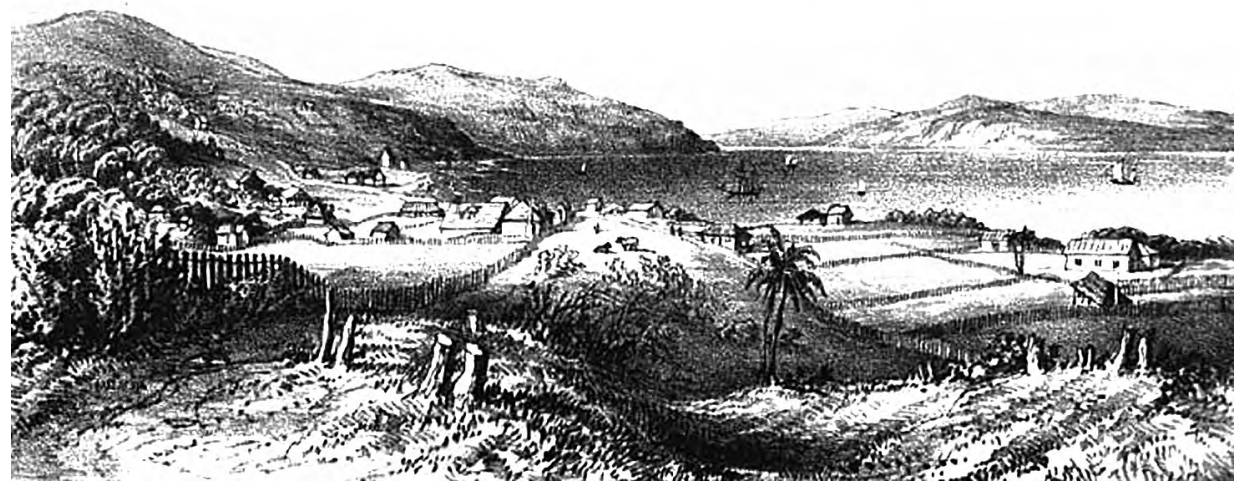

Figure 6: Charles Kettle, 'Dunedin in 1849'.

Source: 'View of Part of Dunedin, and Upper Harbour, from Stafford Street' (1849). This was republished in John Cargill, Otago, New Zealand: Information for the Guidance of Intending Emigrants (Edinburgh: Bell and Bradfute, 1860), no page. Toitū Otago Settlers' Museum CS/2846 (reproduced with permission).

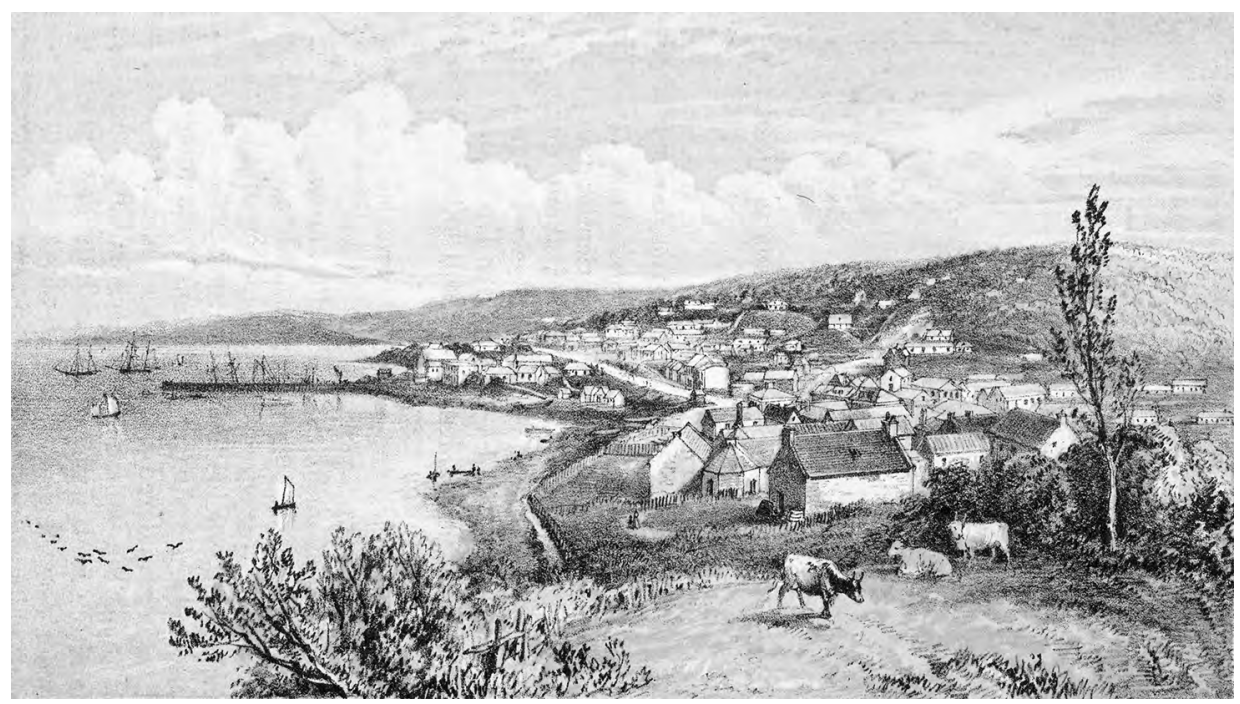

Figure 7: Charles Kettle, 'Dunedin in 1859'.

Source: Cargill, Otago, New Zealand. 
A decade later, the change is striking (Figure 7). There are more permanent-looking houses. Roofs are shingled rather than thatched. The number of masts visible behind the jetty shows the manifold increase in shipping the town had enjoyed since its establishment. The message and contrast is clear: by working hard, the first settlers have brought prosperity through land clearance.

The message of these 2 images, if not the accuracy of the state of Dunedin in its early years, are borne out in descriptions contrasting its early settlement and later development, on the eve of the gold rush that began in 1861. Orbell, late in life, recalled Dunedin in 1849 as consisting of 'a few scattered and hastily erected dwellings'. Not even the town had been completed. A large area of Dunedin was still 'covered with a rank growth of grass, flax, scrub, Toi Toi [pukio, Carex secta] and spear grass'. It was, concluded Orbell, altogether an 'embryo Town' and not at all attractive. A decade later:

civilization had made some progress. I say some progress, because it is difficult to define where it begins or ends. At any rate Dunedin was growing and clearances made, where before bush, scrub, and ... [pukio, Carex secta] existed. The Northern route over Flag Staff Hill had been improved by the erection of stone cairns, also over Swampy Hill, and a horse track partially indicated by the traffic, people were no longer afraid to travel that country alone.

\section{Conclusion}

Whether they grasped it or not, Otago's first generation of European settlers came to a highly modified environment shaped by over 500 years of Māori actions. These later settlers benefited immeasurably from the change from forest to grassland over much of eastern New Zealand initiated by Māori firing, as well as, during the early years of settlement, by the produce grown by Māori, which helped keep Otago's first European colonists fed.

A mutual loathing of industrialisation, combined with the moral glue of Presbyterianism, and the promise of land ownership and independence, provided an intoxicatingly attractive lure to many Free Kirk Scots disillusioned with religious persecution, the impact of enclosure and the loss of rural industries. Although the ideal of a tight-knit, concentrated settlement of God-fearing Scots proved chimerical, the actions of the early immigrants attracted to the Otago Colony had lasting and, in many cases, irrevocable environmental and social effects.

Fired by the ideals of improvement, settlers to Otago set about hewing farms from forests, making gardens in what they perceived as a wilderness, and introducing a host of plants and animals for practical and aesthetic reasons. Alongside this, they introduced farming systems familiar to themselves from home. As this article has shown, the effects of these actions on soils, ecologies and lives were sometimes 
profound, through loss of species and changes to soil composition, as well as removal of forests and an acceleration of erosion. Yet, despite such profound changes, settlers were indifferent neither to the environment around them, nor to the effects of their own actions on it.

As the second part of this article will show, one common way in which settlers encountered the Otago environment was shaped by Romanticism. This gave settlers a framework within which to place various parts of Otago's environment, whether the picturesque wooded sides of Otago Harbour or the Sublime, awe-inspiring scenery of the Southern Alps. The next part of this article will also show the existence of extensive, if sometimes contradictory, efforts to preserve forests both within the town of Dunedin and in the wider Otago Block. Diverse efforts at conservation provoked conflict between some Māori and authorities, as well as within colonial society itself.

\section{Coda}

In 1999 Tom Brooking supervised my BA Honours Long Essay, one of hundreds of Honours dissertations he has overseen, in addition to a staggering 100 masters and doctoral theses. I didn't realise it then, but Tom's influence over this dissertation-coupled with the fourth-year environmental history course on India run by Ruhi Grover and Judith Bennett's Pacific environmental history from the previous year-would put me on a course to becoming an environmental historian myself. I'd especially like to thank Tom for his support, guidance and friendship over the years. 
This text is taken from International Review of Environmental History, Volume 6, Issue 2, 2020, edited by James Beattie, published 2020 by ANU Press, The Australian National University, Canberra, Australia.

doi.org/10.22459/IREH.06.02.2020.05 